\title{
MOBILE EQUIPMENT FINANCING: FEDERAL PERFECTION OF CARRIER LIENS
}

In addition to the countervailing themes and interests underlying all secured commercial transactions, unique considerations should fashion regulation of mobile equipment financing. Secured credit arrangements reflect a triad of conflicting demands. Borrowers need ready sources of constant working capital. ${ }^{1}$ Institutional lenders require security that will not only withstand attack but be so obviously valid as not to invite it. ${ }^{2}$ Unsecured creditors, to preserve recourse against unencumbered assets, must decry secret liens and preferential or fraudulent transfers. ${ }^{3}$ The body of law which aligns these interests has attained tortuous development from initial legislative and judicial hostility toward security transfers despite revolutionary changes in commercial practice. ${ }^{4}$ Basic to all regulation is a fear of the lender's bargaining position. Legislatures have prescribed formalities designed to impress borrowers with the seriousness of a security transaction and to warn unsecured creditors of its existence. ${ }^{5}$ As well as strictly enforcing these prerequisities, courts have evolved further doctrines which imprecisely counter collusive arrangements while needlessly thwarting bona fide transactions. ${ }^{6}$ On the other hand, facilitation of credit is

1. See Honnold, Sales and Sales Financing 369-74 (1954).

2. Comment, 67 YALE L.J. 402,430 n.99 (1958). See also Gilmore \& Axelrod, Chattel Security: I, 57 Yale L.J. 517, 530 (1948); Isaacs, Business Security and Legal Security, 37 HARv. L. REv. 201, 207-09, 212 (1923). If bankruptcy intervenes, a creditor secured by a large proportion of the business assets is in a better position to persuade the trustee to continue operations, thereby generating debt retirement funds. Frederick, Commercial Atr Transportation 456 (rev. ed. 1947).

3. Stumberg, Chattel Security Transactions and the Confict of Laws, 27 Iowa L. Rev. 528, 544 (1942).

4. Birnbaum, Article 9-A Restatement and Revision of Chattel Security, 1952 WIs. L. REv. 348, 349-50; Gilmore \& Axelrod, stpra note 2, at 533. The statutes still contain many vestiges of the prejudice marking an era of small personal property security transactions despite the present multibillion dollar annual volume of secured commercial financing. Ireton, Article 9 of the Uniform Commercial Code-Part III, 6 PErs. F.L.Q. REP. 64 (1950).

5. Witnessing, acknowledgment, notarization, good faith affidavits, value statements, verification and attestation are among the more important prerequisites imposed. See notes 149-52 infra and accompanying text.

6. For example, one court has repeatedly held that failure to record absolutely voids a lien although the lender repossessed the chattels before intervening interests had attached. Cardenas v. Miller, 108 Cal. 250, 39 Pac. 783 (1895); Chelhar v. Acme Garage, 18 Cal. App. 2d 775, 61 P.2d 1232 (1936). Another has allowed an attachment to prevail over an unrecorded mortgage when the security was merely in transit through the state. Pennington County Bank v. Bauman, 81 Neb. 782, 116 N.W. 669 (1908). Still others have evolved an immediate recordation rule invalidating liens when execution and recordation are not virtually simultaneous. Mercantile Trust Co. v. Kahn, 203 F.2d 449 (8th Cir. 1953) (five days unreasonable delay; two hours adequate for recording); Cass v. Rothman, 42 Ohio St. 380 (1884) (eight hours too long a delay). Recordation errors through 
rarely considered as compelling a policy determinant. Yet businesses without credit positions warranting unsecured financing would be the ultimate beneficiaries of the low interest money supply which unimpeachable security devices permit. Influenced by varying social and economic pressures within each jurisdiction, the balancing of these interests and themes has evoked divergent state laws. ${ }^{7}$ Conforming local transactions to the standards of one jurisdiction, though, is not an unduly burdensome process. And with uniformly accepted conflict of laws rules, commercial practicability could be attained in most multistate arrangements. ${ }^{8}$

In the mobile equipment field, however, prevailing conflicts doctrine combines with disparate state laws to make safe financing dependent on the uniform treatment enabled by federal legislation. Lex situs- the law of the place where the thing is located-is usually chosen to govern chattel transfer decisions." While providing uniformity and predictability for arrangements involving immovables, lex situs has proven a formidable obstacle to ship, rail, air and motor truck financing. ${ }^{10}$ Since transportation equipment constantly changes location, creditors require liens perfected in every jurisdiction in which their collateral is likely to operate. ${ }^{11}$ But lien protection has been prob-

'ault of the filing clerk have also caused lien forfeiture. Securities Credit Corp. v. Pindell, 53 Neb. 298, 44 N.W.2d 501 (1950) ; Maryland Credit Finance Corp. v. Franklin Credit inance Corp., 164 Va. 579, 180 S.E. 408 (1935). In bankruptcy cases, one court has "volved a "part-bad, all-bad" rule designed to invalidate in toto liens which are only artially defective. Brown v. Leo, 12 F.2d 350 (2d Cir. 1926); Arbury v. Kocher, 18 .2d 588 (W.D.N.Y. 1927). Sometimes, the slightest word variation in a filed document ill cause avoidance. See General Motors Acceptance Corp. v. Haley, 329 Mass. 559, 109

E.2d 143 (1952) (trust receipt financing statement filed under name of "E. R. Millen o." avoided because word "Inc." omitted). One commentator even discusses cases in which surts, confronted with statutes requiring an affidavit to be "affixed," have debated whether - wire staple was sufficient or whether mucilage was essential. Birnbaum, supra note 4, 3t 350 .

7. Everett, Securing Security, 16 LaW \& Contemp. Prob. $49-51$ (1951).

8. See Comment, 67 Y ALE L.J. 402 (1958).

9. See, c.g., Green v. Van Buskirk, 72 U.S. (5 Wall.) 307 (1866) ; Steckel v. Swift \& Co., 56 S.W.2d 806 (Mo. Ct. App. 1933) ; Youssoupoff v. Widener, 246 N.Y. 175, 158 N.E. 64 (1927). See also United States Fidelity \& Guaranty Co. v. Northwest Engineering Co., 146 Miss. 476, 112 So. 580 (1927). The rule is the same in England. Cammel v. Sewell, 15 H. \& N. 728, 157 Eng. Rep. 1371 (Ex. 1860) ; Hellendall, The Res in Transitu and Similar Problems in the Conflict of Laws, 17 CAN. B. REv. 7 (1939). For general discussion, see Goodrich, Conflict of Laws 474-78 (3d ed. 1949) ; Lalive, The Transfer of Chattels in the Conflict of Laws $34-43$ (1955) ; Stumberg, Conflict of Laws 390-402 (2d ed. 1951).

10. Many motor trucks include two separate units, tractor and trailer. No distinction is made between the two in this Comment. Also, since the bus transportation industry faces problems substantially identical to those confronting the trucking industry, S. REp. No. 701, 85th Cong., 1st Sess. 5 (1957), motor busses and trucks are treated concurrently.

11. Davis, The Trucking Industry-Some Funancial and Credit Aspects 12 (1954); Odle, Financing the Trucking Indistry, Burroughs Clearing House, Jan. 1953, pp. 34, 78. Cf. Great Am. Indemnity Co. v. Utility Contractors, Inc., 21 Tenn. App. 463, 111 S.W.2d 901 (1.937). 
lematical when attempted. ${ }^{12}$ In response to the resulting creditor reluctance to finance, Congress has intervened to regulate security interests in aircraft, railroad and maritime equipment. ${ }^{13}$ The touchstone of this legislation-filing with federal agencies-eliminates multistate perfection difficulties. Nevertheless, the influence of outmoded doctrines pervades the overformalized recordation procedures provided. More important, federal legislation has taken an industry-by-industry approach, ignoring carrier lien perfection similarities and the possible advantages of consolidated statutory coverage. ${ }^{14}$ Recent efforts to secure still another separate federal filing statute for liens on interstate motor carriers suggest reappraisal of the existing regulatory pattern to determine whether continued segregation is desirable as well as to avoid extension of present shortcomings.

\section{SHIPS}

Unique characteristics of admiralty law have shaped the development of secured maritime financing. The first device utilizing ships as security for maritime credit transactions was the hypothecated bottomry-admiralty's equivalent of the chattel mortgage. ${ }^{15}$ While bottomry bonds owed their enforceability to admiralty courts, their defects stemmed from an unusual restriction imposed by those tribunals. ${ }^{16}$ Loss at sea not only deprived lenders of their security but discharged their claims against the borrower's other assets. ${ }^{17}$ Obviously impractical during the more precarious era of the clipper ship, bottomry bonds were largely replaced during the nineteenth century by ordinary

12. The situation has so deteriorated that the trucking industry finds "it is almost impossible to take steps necessary to assure the validity of a lien." S. REP. No. 553, 84th Cong., 1st Sess. 2 (1955). See also Hearing Before the Subcommittee on Surface Transportation of the Senate Committee on Interstate and Foreign Commerce on $S .375, S .938$, S. 940, S. 1385, S. 1721, S. 2031, 85th Cong., 1st Sess. 44 (1957).

13. The Ship Mortgage Act of 1920,41 Star. 1000 , as amended, 46 U.S.C. $\$ \$ 911-84$ (1952) ; Civil Aeronautics Act $\$ 503,52$ Stat. 1006 (1938), as amended, 49 U.S.C. $\$ 523$ (1952) ; Interstate Commerce Act $\$ 20 c$, 66 STAт. 724,49 U.S.C. $\$ 20 \mathrm{c}$ (1952).

14. All federal legislation regulating transportation services is divided by industry because of differing physical operations. This approach has unfortunately been carried over to lien perfection statutes although the same reasons for segregated treatment do not exist. See, e.g., Honnold, op. cit. supra note 1, at 442-43 (noting the similarity of legislation covering rail, air and ship lien perfection, suggesting the necessity for similarly covering trucks and busses, but ignoring the obvious possibility of a combined statute).

15. Hebert, The Origin and Nature of Maritime Liens, 4 TuL. L. Rev. 381, 395-96 (1930). Another early device was the respondentia loan-a lien on the vessel's cargo equivalent to the hypothecated bottomry of the ship. For examples of both security devices, see 1 Benedict, American Admiralty 316, 320 (6th ed. 1940).

16. Bottomry bonds were subject to admiralty jurisdiction even if they partly secured nonmaritime property. The Draco, 7 Fed. Cas. 1032, No. 4057 (C.C.D. Mass. 1835); see The Katherine, 15 F.2d 387 (E.D. La. 1926).

17. The Grapeshot, 76 U.S. (9 Wall.) 129, 135 (1870); Carrington v. The Brig Ann C. Pratt, 59 U.S. (18 How.) 63, 67 (1856). See also Canfield, The Ship MIortgage Act of 1920, 22 MICH. L. Rev. 10 (1923). 
chattel mortgages. ${ }^{18} \mathrm{But}$, again, peculiarities of admiralty law frustrated credit arrangements. Under the ship personification doctrine, vessels are legally responsible for their debts. ${ }^{10}$ Obligations incurred by this fictional entity, such as those for supplies, repairs, towage and wharfarge, automatically created maritime liens which had to be discharged before the vessel could be applied to the owner's personal-nonmaritime-indebtedness. ${ }^{20}$ Their claims denied maritime status by an early Supreme Court decision, ${ }^{21}$ ship mortgagees were left with alternative "remedies": they could foreclose in equity subject to all maritime encumbrances ${ }^{22}$ or intervene in admiralty proceedings to enforce their rights against whatever surplus remained after satisfaction of maritime liens. ${ }^{23}$

In 1920, Congress sought to resolve this dilemma by extending admiralty jurisdiction to ship mortgages. Spurred by the peacetime necessity to dispose of more than 1100 ships acquired by the government during World War I, ${ }^{24}$

18. Gilmore \& Black, Admiralty 570 (1957) (hereinafter cited as Gilmore \& BLACK).

19. The personification theory has one of the most colorful historical backgrounds of any American legal doctrine. It was created by Chief Justice Marshall, sitting on circuit, in the piracy case of United States v. The Little Charles, 26 Fed. Cas. No. 15612, at 982 (C.C.D. Va. 1818) ("[T] his is not a proceeding against the owner; it is a proceeding against the vessel, for an offence committed by the vessel .... It is true, that inanimate matter can commit no offence. The mere wood, iron and sails of the ship, cannot, of themselves, violate the law. But this body is animated and put in action by the crew, who are guided by the master ...."). Then, in The Palmyra, 25 U.S. (12 Wheat.) 1 (1827), Mr. Justice Story, following the pattern, found another vessel guilty of piracy. and therefore forfeitable to the United States. The climax came in the comic opera case of United States v. The Brig Malek Adhel, 43 U.S. (2 How.) 210 (1844). Mr. Justice Story was again confronted with a libel in rem against a ship, this time for the Piratesof-Penzance type acts of her captain. Unlike Palmyra, where the owners had authorized the piratical depredations, the Malek Adhel's master had gone off on a frolic of his own. Nonetheless, the ship was held liable as a separate entity for piratical offenses committed against the United States, and thus forfeiture was ordered.

20. See Piedmont \& Georges Creek Coal Co. v. Seaboard Fisheries Co., 254 U.S. 1, 9 (1920) ; Robinson, Admiralty 363-64 (1939). For historical discussion, see UnderHay, American and English Theories of the Maritime Lien c. 1 (unpublished thesis in Yale Law School Library 1937). See also Price, Marimime Liens c. 1. (1940); Hebert, supra note 15. Typical maritime liens arise from seamen's wages, salvage, tort damages, general average ("partial loss which is incurred when some of the values at risk in the marine venture are sacrificed to save the remainder from peril . . ." GILMORE \& BLACK 73), supplies, repairs, towage, wharfage, pilotage, stevedoring, cargo damages, unpaid freight, charter parties (vessel leases) and bottomry bonds. Id. at 514-18.

21. Bogart v. The Steamboat John Jay, 58 U.S. (17 How.) 399 (1854). Indeed, so sacrosanct was the maritime-nonmaritime dichotomy that in The J. E. Rumbell, 148 U.S. 1 (1892), a state created maritime lien was given precedence over a previously filed ship encumbrance recorded under the federal Vessel Sales and Mortgage Recording Act of July 29,1850 , c. $27, \S 1$, REv. STAT. $\$ 4192$ (1875).

22. Gilarore \& Black 569.

23. The Lottawanna, 88 U.S. (21. Wall.) 558 (1874); The Hendrik Hudson, 11 Fed. Cas. 1087, No. 6358 (N.D.N.Y. 1855).

24. Prior to American entry in World War I, the United States merchant fleet had practically vanished. The entire blame, however, cannot be ascribed to the inutility of 
it passed the Ship Mortgage Act. ${ }^{25}$ Because an effective security interest was imperative to interest private capital in financing the sales, ${ }^{26}$ ship mortgages were given priority over most subsequent maritime liens. ${ }^{27}$ But strict formalities imposed by the statute contributed to the discouragement of private lenders, and sales had to be governmentally financed. ${ }^{28}$ Indeed, as far as private capital was concerned, the act was virtually dormant until 1940.20 Only the increased demand for marine transportation initiated by World War II and continuing to date has enabled the industry to obtain institutional credit. ${ }^{30}$ The security device usually employed is a combination chattel mortgage and

existing security devices. American shipping was suffering from technological stasis. By clinging to the clipper ship long after that colorful vessel had outlived its commercial utility, the industry could not attract private capital. Had a valid security device been badly needed, most likely one would have been created. GILArore \& BLAcK 570 .

25. 41 Stat. 1000 (1920), as amended, 46 U.S.C. $\$ \$ 911-84$ (1952). Ship mortgages had been removed from the domain of state recordation laws by the Vessel Sales and Mortgage Recording Act of July 29, 1850, c. 27, § 1, Rev. STAт. $\$ 4192$ (1875). See White's Bank v. Smith, 74 U.S. (7 Wa1l.) 646 (1868). But that act provided only for the recordation, not status. of mortgage liens. With the enactment of the Ship Mortgage Act, the 1850 statute was therefore repealed. Act of June 5, 1920, c. $250, \S 30(\mathrm{X}), 41$ STAT. $1006(1920)$.

26. The Favorite, 120 F.2d 899, 902 (2d Cir. 1941); RoBinson, AdMIRaLTy 442 (1939).

27. Four maritime liens-seamen's wages, salvage, tort damages and general average -were still preferred over a prior mortgage. 41 StaT. 1004 (1920), 46 U.S.C. \& 953 (1952). See note 20 supra. See also The Eastern Shore, 31 F. Supp. 964 (D. MId. 1940). Government tax liens, however, are generally subordinate to a preferred ship mortgage. -United States v. Flood, 247 F.2d 209 (1st Cir. 1957) ; Gulf Coast Marine Ways v. The J. R. Hardee, 107 F. Supp. 379, 384-85 (S.D. Tex. 1952). For complete discussion of lien-mortgage priorities, see GILAORE \& BLACK 610-16.

28. See notes 34-43 infra and accompanying text. In addition, Congress limited the types of mortgages which could acquire preferred standing. Certain vessels are ineligible. 41 Stat. 1000 (1920), 46 U.S.C. § 922(a) (1952). Moreover, the mortgagee has to be a United States citizen. $I d$. at $\$ 922$ (a) (5). Originally, only mortgages on ships registered as vessels of the United States were eligible, but certain foreign ship mortgages were admitted by a 1954 amendment. 68 Stat. 323 (1954), 46 U.S.C. $\$ 951$ (Supp. V, 1958). This extension of the act primarily benefited American shipping since many United States firms have been registering under foreign flags to escape our extremely stringent shipping regulations. Cf. Lauritzen v. Larsen, 345 U.S. 571, 587 (1953). However, unlike American mortgages, foreign encumbrances are subordinated to certain maritime liens arising from work performed or supplies furnished in the United States. For a review of the legislative history of the 1954 amendment, see Rederiaktierbolaget v. Compania De Navegacion Anne, 139 F. Supp. 327, 334-35 (D.C.Z. 1955). Soe, generally, Lord \& Glenn, The Foreign Ship Mortgage, 56 YAlE L.J. 923 (1947).

29. The widespread failure to take advantage of the act can also be explained in terms of constitutional uncertainty. GILArore \& BLACK 571; see Canfield, supra note 17, at 24; Comment, The Constitutionality of the Ship Mortgage Act, 33 YALE L.J. 646 (1924). Lower federal courts were unanimous in sustaining the act. See, $\varepsilon . g$., The Lincoln Land, 295 Fed. 358, 360-61 (D. Mass. 1923) ; The Nanking, 292 Fed. 642 (N.D. Cal. 1923); The Oconee, 280 Fed. 927, 930-33 (E.D. Va. 1921). Not until 1934, however, did the Supreme Court finally settle the question, Detroit Trust Co. v. The Thomas Barlum, 293 U.S. 21, 42-52 (1934), and by then the depression had curbed commercial financing.

30. See Business Week, April 26, 1958, pp. 120-33. 
contractual assignment. ${ }^{31}$ Widespread separation of vessel ownership and operation underlies this distinctive financial practice. The owner charters-leases -the vessel and assigns the charter party-lease-to the mortgagee. ${ }^{32}$ Actually, the primary security is the hire-rent-to be paid by the charterer, the mortgage considered as secondary insurance foreclosable only on default of both charterer and owner. ${ }^{33}$ Nevertheless, mortgage perfection is necessary and, unfortunately, quite difficult under the statute's recordation provisions.

\section{Statutory Defects}

Insistence on formalities and a detailed recording scheme combine to burden creditors attempting to perfect security interests under the act. ${ }^{34}$ First, the ship must have a "home port" for recordation, selected by its owner and approved by the Maritime Administration. ${ }^{35}$ Failure to secure approval, or filing in the wrong port, invalidates the instrument. ${ }^{36}$ Upon recordation, the

31. Simpson, Ship Financing-A Pancl Discussion, 13 Bus. LAw. 145, 148, 166, 175 (1958). The combination mortgage and assignment are often tied to the trust indenture of a bond issue. Id. at 169-70. Conditional sales contracts, though still subject to state recordation laws, Stewart \& Co. v. Rivara, 274 U.S. 614 (1927), are also occasionally used. Whatever the security device, secured financing remains subject to state recording statutes while ships are under construction. Rodgers, Ship Construction Financing, 12 Bus. Law. 142, 147-51 (1957); see In re Empire Shipbuilding Co., 221 Fed. 223 (2d Cir. 1915) (pre-Mortgage Act case).

32. For discussion of charter party assignments, see Simpson, supra note 31, at 160-66.

33. Id. at 175 .

34. For conditions which must be fulfilled prior to recordation, see 41 STAT. 1002 (1920), 46 U.S.C. $\$ 926$ (1952).

35. 43 Stat. 947 (1925), 46 U.S.C. $\$ 18$ (1952). Even mortgages on vessels which are not entitled to priority over maritime liens, see note 28 supra, must be filed in the ship's home port. Compare 41 STAT. 1000 (1920), 46 U.S.C. \$921 (1952), with id. \$922. The system was adapted from the Vessel Sales and Mortgage Recording Act of July 29, 1850 , c. $27, \S 1$, REv. STAT. $\$ 4192$ (1875), an outmoded model for a modern commercial statute.

36. Maritime Administration consent must be obtained before the mortgage is presented for recordation. The R. Lenahan, $10 \mathrm{~F}$. Supp. 497, 499 (E.D. Pa. 1935). But cf. The Fort Orange, 5 F. Supp. 833, 842 (S.D.N.Y. 1933) (mortgage recordation after the Maritime Administration had orally approved the home port selection but prior to written consent held valid). In common parlance, home port means the port from which the vessel operates. The Mortgage Act does not use the term home port; it requires recordation with the Collector of Customs in the vessel's port of documentation. The latter phrase being undefined, the early practice was home port recordation. Then, in The Susana, 2 F.2d 410 (4th Cir. 1924), the court held the proper port of documentation to be the one nearest the owner's residence or, in the case of a corporation, that nearest the place of inconporation. The effect of this holding was to cast doubt on the preferred status of some 800 mortgages previously recorded by corporations. Congress immediately passed the Home Port of Vessels Act, subdivided into five sections. Section 1, 43 Stat. 947 (1925), 46 U.S.C. § 18 (1952), provides for owner selection of the home port subject to Maritime Administration approval. Sections 2-5, 43 STAT. 948 (1925), 46 U.S.C. \$§ 1011-14 (1952), validated all previous recordations and went on to provide that the port of documentation referred to in the Ship Mortgage Act was the home port defined in $\S 1$. 
Collector of Customs at the home port must indorse the mortgage on the ship's papers. ${ }^{37}$ Should a clerk not record filed documents, or commit other errors in the recording procedure, risk of loss falls on the mortgagee. ${ }^{38}$ And if the Customs Office omits the indorsement, or indorses improperly, preferred standing-priority over maritime liens-is forfeited. ${ }^{30}$ The burden of the indorsement process is increased by the requirement that ship's papers be carried on board at all times. ${ }^{40}$ Many vessels operate under time charters whereby owners relinquish control for extended periods and cannot order return to an American port until the charter party expires. ${ }^{41}$ Since indorsement is obviously impossible during a ship's voyage, ${ }^{42}$ secured financing must await its return. ${ }^{43}$

37. 41 Stat. 1000-01 (1920), 46 U.S.C. $\$ \$ 922$ (a) (1), (a) (2), (d) (1952). If the vessel is in another American port at time of filing, indorsement is to be effected there. The home port Collector will telegraph or mail indorsement instructions to the Collector of the port where the vessel is located at the mortgagees expense. Harbor clearance is not to be granted until the indorsement process is completed. 41 STAT. 1001 (1920), 46 U.S.C. $\S 922(d)(2)$ (1.952).

38. Grrarone \& BlaCK 587. Theoretically, the Collector of Customs is liable for any pecuniary loss resulting from his misfeasance. 41 StAT. 1003 (1920), 46 U.S.C. $\$ 941$ (1952). Whether the Collector is personally or officially liable has never been determined. Judicial reluctance to hold the government responsible in other filing contexts probably underlies the paucity of litigation here. See note 215 infra.

39. Morse Dry Dock \& Repair Co. v. The Northern Star, 271 U.S. 552 (1926); The Bethlehem, 4 F.2d 308 (3d Cir. 1925). Four separate items must be indorsed. 41 Stat. 1001 (1920), 46 U.S.C. $\$ 922$ (c) (1952).

40. See Simpson, supra note 31 , at 172 .

41. Id. at 151-55.

42. Conceivably, the Customs Collector might designate a ship's captain his agent for indorsement purposes during voyage. Whether this has been tried, or would withstand judicial scrutiny, is unknown.

43. For suggested revision, see text at note 213 infra.

Submission of a good faith affidavit in statutorily prescribed form is also required. 41 STAT. 1001 (1920), 46 U.S.C. \$ 922(a) (3) (1952). Failure to include this document invalidates an otherwise preferred mortgage. The Angler, 23 F. Supp. 341, 342 (E.D.N.Y. 1938). Moreover, any deviation from the language of the affidavit requirement is an invitation to litigation although the cases raising the question have not resulted in invalidation. Gulf Coast Marine Ways v. The J. R. Hardee, 107 F. Supp. 379, 386-87 (S.D. Tex. 1952); The Nan B., 78 F. Supp. 748 (D. Alaska 1948); see The Eastern Temple, 94 F.2d 374, 377 (4th Cir. 1938). The number of other trifling irregularities that can arise are manifold. Many may stem from the provision requiring enrollment as a vessel of the United States before preferred status will be granted. 41 STAT. 1000 (1920), 46 U.S.C. $\$ 922$ (a) (1952). The Shipping Code provides that a vessel of the United States is any ship registered pursuant to law. REv. STAT. § 4131 (1875), as amended, 46 U.S.C. \& 221 (1952). Registration is governed by chapter two of the Shipping Code, 46 U.S.C. $\S \S 11-63$ (1952), which is so intricate that many American firms have been registering under foreign flags to escape it, see Lauritzen v. Larsen, 345 U.S. 571, 587 (1953). Indeed, only judicial refusal to surrender substance to form has prevented the statutory scheme from becoming useless. See, e.g., Pilgrim Trust Co. v. The Frances C. Denehy, 94 F. Supp. 807, 814-15 (D. Me. 1950) (failure to comply with the requirement that a certified copy of the mortgage be carried on board ship does not forfeit preferred status); Collier Advertising Serv., Inc. v. Hudson River Day Line, 14 F. Supp. 335 (S.D.N.Y. 1936) 
Moreover, inadvertent waiver of lien priority may occur despite valid recording and indorsement. Section 922 (a) (4) provides that "the mortgage ... [must] ... not stipulate that the mortgagee waives the preferred status thereof ..., "44 an anomalous provision whose primary function to date has been harassment of the admiralty bar. ${ }^{45}$ Any clause in a mortgage which recognizes superior rights to a vessel may constitute, under section 922(a)(4), an involuntary relinquishment of preferred standing. For example, a Maritime Administration regulation requires any mortgage covering a vessel built in an American shipyard for a foreign owner to acknowledge forfeiture rights in the United States government. ${ }^{4 B}$ The regulation is apparently designed to protect any interest the United States, or its citizens, might have in the ship against foreclosure or judicial sales effected without Administration approval. But since it forces acknowledgment of superior rights in another party, compliance may be deemed tantamount to a waiver under the act. ${ }^{47}$ Similar loss of priority might flow from those clauses in mortgages obtained with charter party assignments by which the mortgagee admits possessory rights in the vessel's charterer. ${ }^{48}$ The scope of the statutory waiver has not yet been satisfactorily defined by the courts. ${ }^{49}$ Even if delineation were possible, section 922(a) (4), which protects neither shipowner nor unsecured creditor while

(corporate owner required to give a certain oath through its president or secretary; court rejected the argument that an oath given by the vice-president invalidated the mortgage); The Fort Orange, 5 F. Supp. 833, 841-42 (S.D.N.Y. 1933) (statute requires documentation in corporate president's or secretary's name; held documentation in corporate name sufficient).

44. 41 STaT. 1001 (1920), 46 U.S.C. § 922(a) (4) (1952).

45. Simpson, supra note 31 , at $173-74$. In discussing this clause, a leading treatise states: "On the face of it, this seems to be an idiotic statement; indeed, it is an idiotic statement." Gilmore \& Black 583.

46. Amend. 2 to Statement of Policy, Fed. Maritime Bd., 22 FEd. Reg. 7397 (1957).

47. Simpson, supra note 31, at 173. For a general statement of Maritime Administration policy on foreign purchase and operation of American vessels, see 46 C.F.R. $\S 221.13$ (III) (Supp. 1957).

48. Relying on a series of English cases, The Heather Bell, [1901] P. 272 (C.A.); Laming \& Co. v. Seater, 16 Sess. Cas. 828 (Scot. 1889) ; Keith v. Burrows, 2 App. Cas. 636 (P.C. 1877) ; Collins v. Lamport, 34 L.J. Ch. 196, 46 Eng. Rep. 1012 (1864), the admiralty bar has concluded that such provisions do not amount to waivers, Simpson, supra note 31, at 173-74. Nineteenth-century foreign decisions seem an unrealistic foundation, however, for an opinion on what an American court, confronted with the act's "idiotic" waiver provision, will do in the mid-twentieth century.

49. What little case law exists only adds to the confusion; no court has ever made any sense out of the provision. Compare Atlantic Steamer Supply Co. v. The Tradewind, 144 F. Supp. 408, 418 (D. Md. 1956) (not a waiver to recognize the existence of possible future liens for repairs and supplies), with The Henry W. Breyer, 17 F.2d 423, 432 (D. Md. 1927) (clause allowing master to incur liens for supplies constitutes waiver); see Crofton Diesel Engine Co. v. Puget Sound Nat'1 Bank, 205 F.2d 950, 951 (9th Cir. 1953) (clause allowing mortgagor to incur debts "for strictly current operations and repairs" does not forfeit preferred status). 
jeopardizing bona fide security transactions, should be deleted from the statute..$^{50}$

Multicollateral transactions encounter further difficulties. Section 922(e) provides that mixed mortgages covering vessel and shore property which do not allot a separate discharge figure to the nonmaritime security are ineligible for preferred standing. ${ }^{51}$ In contrast, section $922(\hat{\mathrm{f}})$, which requires separate discharge figures for multivessel mortgages, does not penalize noncompliance with forfeiture of maritime status. ${ }^{52}$ Comparison of the two sections indicates that section 922(e) may in part stem from congressional apprehension of extending admiralty jurisdiction to encumbrances of nonmaritime property. ${ }^{63}$ The function of separate discharge figures in other contexts-to enable creditors to determine when specific assets are released from prior liens-may also explain section 922(e)'s enactment. In operation, however, the section accomplishes neither objective. Since liens on shore property are not protected by filing mixed mortgages under the act, ${ }^{54}$ the purity of admiralty jurisdiction would be unimpaired by deletion of the separate discharge requirement. Moreover, the act fails to provide an allocation formula for a borrower's installment payments. ${ }^{j 5}$ The mortgagee is apparently free to apply remittances against either maritime or nonmaritime security although the only case in point sug-

50. Still another Mortgage Act formality requiring clarification is the limitation of recordation jurisdiction to liens encumbering "the whole of any vessel of the United States." 41 Stat. 1000 (1920), 46 U.S.C. $\$ 922$ (a) (1952). In The R. Lenahan, 10 F. Supp. 497, 501 (E.D. Pa. 1935), the clause was interpreted to exclude the vessel's freight. The decision is sound. In a long term financing arrangement, the mortgagee is not interested in the cargo; therefore it should not be forced on him as a prerequisite to preferred status. GilaroRe \& BLACK 583.

51. 41 Stat. 1000 (1920), 46 U.S.C. $\$ 922(\mathrm{e})$ (1952). If a vessel's freight is encumbered, however, it does not fall under the "property other than a vessel" clause. The R. Lenahan, supra note 50 , at 501 .

52. 41 Stat. 1000 (1920), 46 U.S.C. $\$ 922$ (f) (1952).

53. See The Emma Giles, 15 F. Supp. 502, $50 \$$ (D. Md. 1936). At the time $\$ 922(\mathrm{e})$ was drafted, the constitutionality of extending admiralty jurisdiction even to mortgages of maritime property was doubted. See note 29 supra. See also The Lottawanna, SS U.S. (21. Wall.) 558, 576 (1874) (admiralty jurisdiction "exclusively a judicial question, and no ... act of Congress can make it broader ... than the judicial power may determine those limits to be").

54. The act expressly limits mortgage validity attained through recordation to the vessel portion of the lien. 41 STAT. 1000 (1920), 46 U.S.C. $\$ 921$ (a) (1952).

55. In contrast, $\S 922(\mathfrak{f})$ 's multivessel clause does contain an allocation formula. The court is to determine the proportion that the value of the ship in question bears to the value of all encumbered vessels, then increase the amount constituting the same proportion of the total mortgage by $20 \%$ to arrive at the separate discharge figure. For example, three ships are mortgaged for $\$ 100,000$. A libel is filed against Ship $A$. The court finds Ship $A$ worth $\$ 40,000$, Ship $B$ also $\$ 40,000$ and Ship $C \$ 80,000$. Ship $A$ 's value is one fourth of the total. Applied to the $\$ 100,000$ lien, one fourth plus $20 \%$ thereof results in a $\$ 30,000$ separate discharge total. The formula provides some certainty for claimants interested in determining the amount needed to free their security from the prior mortgage, to the extent their appraisal substantially coincides with that of the courts. 
gests that courts are not bound by his distribution. ${ }^{56}$ At any rate, far from being enlightened by a separate discharge figure, creditors holding secondary liens on ship or shore property can only ascertain the existence or release of superior encumbrances by forcing litigation. In practice, financing parties can easily satisfy section 922 (e) or avoid it entirely by drafting separate instruments. ${ }^{57}$ Nevertheless, to protect less carefully planned arrangements from a functionless proscription, as well as to modernize the act, section 922(e) should either be eliminated or supplemented with an allocation formula.58

\section{Aircraft}

Airline equipment financing has assumed significant proportions only during the past decade. ${ }^{59}$ In the aviation industry's formative years, the speculative nature of its future as well as the difficulty of perfecting liens in every state through which aircraft were likely to operate made secured financing unattractive to institutional lenders. ${ }^{60}$ Equity capital, government air mail subsidies and retained earnings formed the primary sources of funds. ${ }^{61}$ Enacting section 503 of the Civil Aeronautics Act in 1938, Congress authorized exclusive recordation of aircraft title and security interests with the CAA. ${ }^{62}$ But while multistate filing difficulties had thus been resolved, and the industry had attained reliable investment stature, further problems discouraged institutional lenders from financing the rebuilding program necessitated by the technological ad-

56. The Emma Giles, 15 F. Supp. 502 (D. Md. 1936).

57. The separate instrument solution is probably wisest, especially since no advantages accrue to a mixed mortgage. GrLMoRe \& BLACK 581-82. For an example of some of the difficulties occasioned by a combined lien, see Collier Advertising Serv., Inc. v. Hudson River Day Line, 14 F. Supp. 335, 339 (S.D.N.Y. 1936).

58. Recent developments militate for immediate revision of the entire Mortgage Act. A huge shipbuilding program is already under way and is expected to continue for at least the next decade. Business Week, April 26, 1958, pp. 120-33.

59. For a summary of prewar aircraft financing, see Hoadley, Banks Opening Books to Personal Plane Financing, Av. Week, Sept. 1945, p. 187. For the industry's present financial position and outlook, see Forbes, Jan. 1, 1958, pp. 23-26; N.Y. Times, Feb. 16, 1958, p. F.1, col. S, p. F.4, col. 3.

60. See, generally, Calkins, Creation and International Recognition of Title and Security Rights in Aircraft, 15 J. ARR L. \& Comr. 156, 157-61 (1948). Until 1945, the combined debt of all airlines never exceeded more than $\$ 10,000,000$ at any one time. Adkins \& Billyou, A Proposed New Form of Security for the Senior Debt of Our Airlines and Railroads: Floating Charges, 12 Bus. Law. 378, 381 (1957). And as of Jan. 1, 1946, no airline had any funded debt. Frederick, Commerctal Air Transportatton 452 (rev. ed. 1947).

61. Adkins \& Billyou, Devclopments in Commercial Aircraft Equipment Financing, 13 Bus. LAw. 199 (1958); FreDERICK, op. cit. sulpra note 60, at 452-54.

62. 52 StAT. 1006 (1938), as amended, 49 U.S.C. $\S 523$ (1952). For a summary of the section's historical background, see RHYNe, Crvil AERonautics ACT Ainnotated 15052 (1939). See also Mickelson, Aircraft Lien Law and Procedure, 44 ILt. B.J. 863 (1956) (technical aspects of lien recordation). As used in this Comment, CAA denotes the Civil Aeronautics Administration, which is the department in charge of aircraft lien recordation. See Historical Note following 49 U.S.C.A. \$ 523 (1951). 
vances and equipment depreciation of World War II. ${ }^{63}$ Airplane titleholders are subject to strict liability for tort damages. ${ }^{64}$ Lenders retaining title for security purposes would, accordingly, risk damage suits for injuries inflicted by encumbered planes. ${ }^{65}$ Under conditional sales and equipment lease arrangements, a secured party is legally the owner until the debt is retired.$^{66} \mathrm{~A}$ chattel mortgagee's status depends on whether the relevant jurisdiction follows the "title" or "lien" theory of mortgages. ${ }^{67}$ Obviously safest of the three devices, the chattel mortgage was almost exclusively used in the few pre- and postwar financing arrangements executed. ${ }^{68}$ Nevertheless, until a 1948 amendment to the Civil Aeronautics Act removed the tort liability obstacle, large-scale financing was needlessly curtailed. ${ }^{69}$

Another factor marking 1948 as the turning point in airline financing was the "basket lien" amendment to section $503 .^{70}$ Apart from potential tort liability, postwar financing was hindered by the Civil Aeronautics Act's failure to provide for centralized filing of basket liens covering airline spare parts inventories. ${ }^{71}$ Mortgages on spares, often worth twenty-five per cent of a plane's

63. Adkins \& Billyou, Developments in Commercial Aircraft Equipment Financing, 13 Bus. LAw. 199 (1958).

64. This rule obtains under both the common law, Prentiss v. National Airlines, 112 F. Supp. 306, 312 (D.N.J. 1953), and the UnrForm AERonautrcs ACT $\$ 5$, in force in twenty-one jurisdictions, 9 UNIFORM LAws ANN. p. xix.

65. No case has arisen in which liability was imposed on a security titleholder. Still, the fear of liability definitely existed, FrEDERICK, op. cit. supra note 60 , at 460-61; Hines, Legal Difficulties in Secured Airline Equipment Financing, 15 J. AIR L. \& CaM. 11, 15 (1948), and impeded airline financing for many years. Similar fears attended early automobile and truck financing but were dispelled as courts almost uniformly held that the security titleholder was not an "owner" for tort or other liability purposes. See, e.g., Furnanen v. Nicksa, 228 Mass. 346, 117 N.E. 325 (1917) ; State v. One Pontiac Coach Automobile, 55 S.D. 8, 224 N.W. 176 (1929).

66. See, e.g., Enterprise Fuel Co. v. Jones, 99 F.2d 928 (4th Cir. 1938) ; Helena Wholesale Grocery Co. v. Interstate Grocer Co., 196 Ark. 454, 118 S.W.2d 857 (1938); Manlove v. Maggart, 111 Ind. App. 398, 41 N.E.2d 633 (1942).

67. "Title" states deem the mortgagee the legal owner. See, e.g., Manufacturers" Finance Acceptance Corp. v. Woods, 222 Ala. 329, 330, 132 So. 611, 612 (1930) ; People v. Scudder, 177 App. Div. 225, 163 N.Y. Supp. 739 (3d Dep't), aff'd, 221 N.Y. 670, 117 N.E. 1080 (1917) ; Howard v. McPhail, 37 R.I. 21, 23, 91 Atl. 12, 13 (1914). On the other hand, "lien" theory jurisdictions hold that title remains vested in the mortgagor. See, c.g., First Nat'1 Bank v. Yuma Nat'l Bank, 30 Ariz. 188, 192, 245 Pac. 277, 278 (1926) ; Hillman v. Morton, 9 Ky. L. Rep. 198 (1887); OrLA. Stat. Ann. tit. 42, $\$ 10$ (Supp. 1957).

68. Adkins \& Billyou, A Proposed New Form of Security for the Senior Debt of Our Airlines and Railroads: Floating Charges, 12 Bus. Law. 378, 381-82 (1957).

69. 62 STAT. 470 (1948), 49 U.S.C. $\$ 524$ (1952). Statutory coverage is limited to the United States. Nevertheless, liability insurance can afford adequate protection against damages caused in international flight. Adkins \& Billyou, Developments in Commercial Aircraft Equipment Financing, 13 Bus. Law. 199, 208 (1958).

70. 62 STAT. 494 (1948), 49 U.S.C. \& 523 (1952).

71. Hines, supra note 65, at 17-19. Mr. Hines' proposed draft of a statutory amendment was substantially adopted by Congress. See $i d$. at 25 . See, generally, FREDERICK, op. cit. supra note 60 , at $456-57$. 
value, not only enhance collateral but preclude other lenders from foreclosing liens on equipment needed to generate debt retirement funds. ${ }^{72}$ Since financers are as interested in a borrower's ability to repay as in the market value of the collateral, ${ }^{73}$ institutional credit became accessible to the airline industry once basket lien perfection with the CAA was authorized. ${ }^{74}$ The chattel mortgage, which gained currency under the threat of tort liability, has proven the most useful device to secure both aircraft and equipment. ${ }^{\mathbf{7 5}}$

72. Since aviation equipment rapidly depreciates unless operated, and is subject to strict governmental inspection and overhaul regulations, see $i d$. at c. 13, aircraft are immobile, and consequently unable to generate debt retirement funds, without a substantial parts inventory, see N.Y. Times, May 26, 1958, p. 29, col. 1 (spare parts keep aircraft "ageless").

73. Financers generally insist that aircraft spares be included in their security interest. See Adkins \& Billyou, Developments in Commercial Aircraft Equipment Financing, 13 Bus. LAw. 199, 203 (1958). Even before basket liens were available, financers carefully examined the airline's plans for maintaining spare parts inventories before approving a loan. FREDERICK, ap. cit. supra note 60 , at 456 .

74. Another reason underlying enactment of the basket lien provision was to conform with the Convention on International Recognition of Rights in Aircraft, June 19, 1948, T.I.A.S. No. 2847 (effective Sept. 17, 1953). For an annotated text of the Convention, see 16 J. AIR L. \& CoMr. 70 (1949). For discussion, see Wilberforce, The Intemational Recognition of Rights in Aircraft, 2 INT'L L.Q. 421 (1.948). Article X recognizes spare parts liens if valid under local law. Shortly before the Convention draft was signed, the American delegate published an article in which he pointed to the need for conforming federal legislation. Calkins, supra note 60 , at 178 (also discusses the Convention's historical background and analyzes the major sections). Undoubtedly, his article influenced congressional action since the basket lien provision was passed simultaneously with the United States' signing of the Convention. While a great improvement on existing law, the Convention unfortunately has had little practical effect since only six nations have ratified it, and two, Chile and Mexico, have included reservations making their ratification unacceptable to the United States. U.S. Dep'T of STATE, TREATIES IN ForCE 152 (1955).

Section 503 has two separate provisions for recording liens on engines. Section 503 (a) (2) allows specific liens against aircraft engines of more than 750 rated take-off horsepower. Section 503(a) (3) provides that any engine may be encumbered under a general basket lien. In practice, liens on engines meeting the statutory specification are always separately recorded. The double perfection provision is included to conform with the Convention. Hines, supra note 65 , at 21-22. To obviate possible confusion, $\$ 503$ (d) gives liens on specific engines recorded under $\S 503$ (a) (2) preference over prior as well as subsequent basket lien encumbrances perfected under $\$ 503$ (a) (3).

75. Adkins \& Billyou, Developments in Commercial Aircraft Equipment Financing, 13 Bus. LAw. 199, 200-01 (1958). Conditional sales financing is inexpedient because parts are manufactured by many different firms. Several contracts would always be required, the total varying with the number of different sellers. And eauinment leasing is not readily adaptable to encumbering small parts.

However, because of the complexities involved in hypothecating both equipment and parts, some of the stronger airlines have obtained funds through unsecured debenture bond sales to institutional investors. Adkins \& Billyou, $A$ Proposed New Form of Security for the Senior Debt of Our Airlines and Railroads: Floating Charges, 12 Bus. Law. 378, 390 (1957). 


\section{Statutory Defects}

Limited to recordation functions, section 503 fails to protect basket liens from Benedict $v$. Ratner strictures. ${ }^{76}$ The Benedict doctrine, followed by many state courts ${ }^{77}$ and generally operative in bankruptcy, ${ }^{78}$ invalidates security arrangements which permit borrowers to exercise dominion over encumbered chattels or proceeds of their sale. The manipulation of spare parts inventory necessitated by airline operations could easily be viewed as dominion inconsistent with the existence of a valid lien. ${ }^{79}$ And while Benedict may be satisfied in other contexts by substituting inventory of equal value for dissipated security or by promptly remitting proceeds of sale, ${ }^{80}$ neither practice may be feasible in the aviation industry. For example, a Company $A$ plane needing a new component might land at an airfield containing only a Company $B$ com-

76. 268 U.S. 353 (1925). For discussion of Benedict in the closely analogous inventory financing field, see Note, 101 U. PA. L. Rev. 392 (1952); see also Comment, 67 YaLE L.J. 847, 877-88 (1958) (contractual assignments). Its possible applicability to spare parts financing is disturbing counsel for institutional lenders financing the commercial airlines. Despite the existence of $\$ 503$, some banks have deliberately foregone basket liens to avoid the danger of invalidation. Adkins \& Billyou, A Proposed New Form of Security for the Senior Debt of Our Airlines and Railroads: Floating Charges, 12 Bus. Law. 378, 390-91 (1957).

77. See, e.g., Stulz-Sickles Co. v. Fredburn Constr. Corp., 114 N.J. Eq. 475, 169 Atl. 27 (Ch. 1933); Chambers v. Hot Lake Sanatorium, 151 Ore. 20, 45 P.2d 1045 (1935); In re Advance Woodwork Co., 231 Wis. 260, 285 N.W. 747 (1939). See also Note, 24 N.Y.U.L.Q. REv. 598 (1949). States partially or totally repudiating Benedict are listed in Comment, 67 YALE L.J. 402,417 n.45 (1958). In deciding Benedict, Mr. Justice Brandeis purported to apply New York law. 268 U.S. at 360-61. Commentators have since argued that the case was not supported by the law of that state. 2 GLENN, Fraudulent Conveyances and Preferences $\$ \$ 592-93$ (rev. ed. 1940); Cohen \& Gerber, Mortgages of Accounts Receivable, 29 GEo. L.J. 555, 559-62 (1941). Some commentators have concluded that Benedict has become a part of the federal common law. 4 Colr.rer, BankRUPTCY $\{70.77$, at 1396 (14th ed. 1942); Cohen \& Gerber, supra at 562-63.

78. 4 CoLlier, op. cit. supra note 77, at If 70.77; Lowenstein, Assignments of Acconnts Receivable and the Bankruptcy Act, 1 Rutgers L. Rev. 1, 11 (1947). All federal circuit courts probably recognize Benedict; in many the doctrine is frequently employed. See Manchester Nat'l Bank v. Roche, 186 F.2d 827 (1st Cir. 1951); Irving Trust Co. v. Finance Serv. Co., 63 F.2d 694 (2d Cir. 1933) ; In re Pusey, Maynes, Breish Co., 122 F.2d 606 (3d Cir. 1941); Union Trust Co. v. Peck, 16 F.2d 986 (4th Cir. 1927); M. M. Landy, Inc. v. Nicholas, 221 F.2d 923, 925 n.1. (5th Cir. 1955); In re Allied Products Co., 134 F.2d 725 (6th Cir. 1943) ; Ed Hughes Furniture Co. v. Caughran, 218 F.2d 906 (7th Cir. 1955) ; McCluer v. Heim-Overly Realty Co., 71 F.2d 100 (Sth Cir. 1934); Scandanavian-American Bank v. Sabin, 227 Fed. 579 (9th Cir. 1915) (pre-Benedict application of doctrine); Midwest Production Co. v. Doerner, 70 F.2d 194 (10th Cir. 1934).

79. For example, the parts are installed or removed at many different terminals both here and abroad, are freely exchanged between the airlines and are interchanged with privately operated central maintenance bases where a substantial portion of the major repair work is performed. Adkins \& Billyou, A Proposed New Form of Security for the Senior Debt of Our Airlines and Railroads: Floating Charges, 12 Bus. LAw. 378, 390-91 (1957).

80. Dunham, Inventory and Accounts Receivable Financing, 62 HARv. L. REv. 588, 596, 598 (1949); Cohen \& Gerber, supra note 77, at 567-68. 
plete parts depot. ${ }^{81}$ Once installed, the new fixture would be covered by the plane mortgage, the collateral securing a basket lien on Company $B$ 's inventory correspondingly diminished. Although adjustments between all airlines for similar replacements need be eventually effected, constant maintenance of airline inventory at prescribed levels, or immediate payment for displaced equipment, may be commercially impracticable. ${ }^{82}$ Moreover, a company's use of its own encumbered inventory for aircraft repairs might also constitute a Benedict violation. True, the installation of spare parts might only represent a shift of collateral between two liens-airplane and basket mortgages-held by the same financer. But even if accretion in the plane's value equalled depletion in inventory, such substitution might not preclude formal application of the Benedict rule.

Benedict's potential application to airline financing should, therefore, be foreclosed. Two interpretations of Benedict's equivocal rationale pertain to spare parts mortgages. ${ }^{83}$ Courts have explained the doctrine as premised on the conceptual incompatability of an absolute conveyance with unfettered dominion in the transferor. ${ }^{84}$ If, in fact, Benedict rests on mere conceptualism, its displacement by pragmatic goals would sacrifice only logical symmetry. On the other hand, Benedict may be viewed as embodying a policy against "too easy" security transfers ${ }^{85}$ which in its original context-accounts receivable financing-complements the interests of institutional assignees. In receivables transactions, Benedict requirements represent minimal standards which responsible lenders would observe absent the decision to prevent dissipation of collateral. ${ }^{8 B}$ As a legal requirement, the doctrine facilitates their patrolling the conduct of assignors who may otherwise feel they are being distrusted. ${ }^{87}$ Airline financers, too, demand that the initial mortgaged level of spare parts inventory be maintained. 88 But if mortgagors were required to replace parts immediately after installation-as assignors must substitute accounts-the too

81. See, generally, FreDERICK, op. cit. supra note 60 , at 637 .

82. The manifold variety and number of airframe and engine parts would militate against prediction of a given plane's replacement needs sufficiently accurate to insure immediate payment or substitution.

83. A third prevailing interpretation of Benedict-to prevent fraudulent backdating of accounts, see Comment, 67 YaLE L.J. 402, 434 (1958) -is not relevant to the discussion in text.

84. See L. Hand, J., in Brown v. Leo, 12 F.2d 350, 351 (2d Cir. 1926) : "[T]he doctrine [of Benedict $v$. Ratner] has nothing to do with ostensible ownership. Therefore it can rest only upon some supposed conceptual repugnancy between the mortgage and the reserved power, quite regardless of any evils which may result from their coupling."

85. Gilmore, Clattel Security: II, 57 YaLE L.J. 761,777 n.58 (1948).

86. Comment, 67 Yale L.J. 402, 405 n.17 (1.958).

87. See National Conference of Commercial Receivable Conpanies, Inc., Eighth Annual Convention of the Commerctal Finance Industry 170-74 (1952); cf. Malcolm, Explanation and Aralysis of Massachusetts House Bill No. 642, Mass. L.Q., Oct. 1945, pp. $26,37$.

88. See FredERICK, ap. cit. supra note 60 , at 456. 
easy rationale could operate to make spare parts financing impossible. ${ }^{80}$ Some courts may realize that one industry's useful practices spell impracticality for the airlines and permit greater time for replenishing collateral. Yet to avoid needless invalidation under strict adherence to Benedict, basket liens should be insulated from the rule.

Protection of security interests during the usual time lapse between mailing and receipt for recording is also indicated. Section 503 holds liens perfected from the date of their "filing for recordation." The ambiguity inherent in this phrase is illustrated in a recent California decision. ${ }^{91} \mathrm{~A}$ mortgage mailed February 9th was received by the CAA on February 14th and forwarded to its Administrative and Records Branch on February 15th. Because of a technical error, the mortgage was returned. The mortgagee corrected the error and refiled on March 4th. In the meantime, intervening interests had attached. While the court dated perfection from February 15th, thus upholding the security interest, the potential vulnerability of other aircraft liens was revealed. ${ }^{92}$ Loss or delay in the mails, or any time lapse during intradepartmental transmission, represent significant risks to the financing party. ${ }^{93}$ The danger can be avoided in major transactions by correlating execution with simultaneous recordation in Washington. But coordinating central perfection with execution at a geographically distant point would be impractical for small

89. See note 82 supra.

90. 52 Stat. 1006 (1938), as amended, 49 U.S.C. \$ 523(d) (1952).

91. Kerley Chemical Corp. v. Colboch, 145 Cal. App. 2d 509, 302 P.2d 621 (1956).

92. Although this court dated perfection from the time of original receipt, another might find perfection effective when the corrected instrument was remailed or refiled. See Anderson v. Triair Associates, Inc., 1949 U.S. Av. R. 440 (Milw. Cty. Ct. 1947) (lengthy delays by CAA in recording mortgage caused subordination of lien); cf. Maryland Credit Finance Corp. v. Franklin Credit Finance Corp., 164 Va. 579, 180 S.E. 408 (1935) (motor truck lien recordation).

93. Moore v. Bay, 284 U.S. 4 (1931), operates in conjunction with $\S 70(\mathrm{e})$ of the Bankruptcy Act, 30 STAT. 566 (1898), as amended, 11 U.S.C. $\$ 110$ (e) (1952), to avoid security interests in toto where any other creditor, however small his claim, has a superior right in the collateral under state or federal law. See notes 157-59 infra and accompanying text. Thus, interests which attach during the interim between execution and filing of an aircraft security instrument could occasion total invalidation under $B a y$ and $\$ 503$ should bankruptcy ensue. In major transactions, informed airline counsel would insist that intervening liens be discharged so that no creditor with a superior claim to the collateral could exist in the event of subsequent bankruptcy. But in small arrangements, financers are not likely to become aware of intervening interests. Moreover, invalidation in bankruptcy may conceivably occur even absent an actual interim creditor. See discussion of Constance v. Harvey, 215 F.2d 571 (2d Cir. 1954), notes 160-65 infra and accompanying text. Since Constance is based on state law, it would be applicable only if $\S 503$ leaves state substantive law on perfection unimpaired. More likely, however, $\S 503$ supersedes substantive law arising out of state recordation acts by superseding the statutes themselves. See, generally, Adkins \& Billyou, Developments in Commercial Aircraft Equipment Financing, 13 Bus. LAw. 199, 206 (1958). Until litigation develops, though, uncertainty necessarily exists. 
plane financings. ${ }^{94}$ The problem should be resolved by statutory amendment permitting promptly mailed instruments to be perfected from the time of execution. ${ }^{95}$ Similarly, provision should be made for validating an improper but good faith filing from the date of original execution if the error is corrected, and the papers refiled, within a reasonable time..$^{96}$

Amendment should also rectify the act's overprotection of secured financers in relation to mechanics lienors. Priority between security interests and subsequently acquired mechanics liens is a traditional problem of commercial law. Section 503, providing that recorded instruments shall be valid against "all persons," apparently resolves the conflict in favor of secured parties. ${ }^{97}$ Of the two cases arising under the act, one strictly applied the statutory language ${ }^{88}$ while the other preferred the mechanics lienor on a constructive notice technicality. ${ }^{90}$ Neither approach complements the policy considerations involved. Arguably, mortgagees should not be subordinated to liens arising from collateral repairs to which they have not consented. On the other hand, mechanic's

94. See, generally, Mickelson, Aircraft Lien Lawe and Procedure, 44 Ir.. B.J. 863 (1956).

95. To accord with the Bankruptcy Act's $\S 60$ (a) (7) delayed perfection provision, 30 SтAт. 562 (1898), as amended, 11 U.S.C. $\$ 96$ (a) (7) (1952), a twenty-one day delay should be the maximum allowable period.

96. Another congressional oversight needing correction is the recent $\$ 116(5)$ "airline" amendment to the Bankruptcy Act, 71 STAT. 617 (1957), 11 U.S.C. $\$ 516(5)$ (Supp. V, 1958), providing that the title of a lessor or conditional vendor of aircraft shall not be impaired by bankruptcy reorganization proceedings. Railroad financers have enjoyed a similar provision for years, 49 STAT. 922 (1935), as amended, 11 U.S.C. $\$ 205$ (j) (1952), which has facilitated equipment financing under lease or conditional sale arrangements. The instant amendment, also designed to encourage commercial investment, is practically useless in its present form. For it does not cover chattel mortgages, the most extensively employed airline security device. See note 75 supra and accompanying text. The error may iprove unsubstantial if airline counsel can frame a combination plane lease and parts mortgage. A better solution, obviating the necessity for encumbering planes separately from their parts inventory, would be congressional insertion of a clause protecting a chattel mortgage under $\S 116(5)$. For discussion, see Adkins \& Billyou, Developments in Connmercial Aircraft Equipment Finlancing, 13 Bus. LAw. 199, 208-12 (1958). An additional advantage of integrated encumbrancing would be avoidance of possible application of Benedict v. Ratner strictures when parts are shifted from inventory to plane. See text following note 82 supra.

97. 52 Stat. 1006 (1938), as amended, 49 U.S.C. \$ 523(d) (1952).

98. In $r \varepsilon$ Veterans Air Express Co., 76 F. Supp. 684 (D.N.J. 1948) (mortgage recorded prior to performance of repair work held superior to mechanics lien).

99. United States v. United Aircraft Corip., 80 F. Supp. 52 (D. Conn. 1948) (plane mortgage omitting description of specific engines removed for repairs held not to protect these parts against a mechanics lien arising from the work done); cf. Anderson v. Triair Associates, Inc., 1949 U.S. Av. R. (Milw. Cty. Ct. 1947). But cf. Modern Air Transport, Inc. v. Pacific Airmotive Corp., 20 N.J. Super. 609, 90 A.2d 108 (L. 1952) (state statute giving mechanics lien to plane repairman held inapplicable to engine repairs; mortgage recordation not an issue). Under existing law, engines not enumerated in aircraft mortgages may automatically be encumbered by basket liens. See note 74 supra. Yet United Aircraft still pertains to all undescribed parts when the airplane mortgagee does not hold a basket lien on spare equipment. 
repairs economically benefit the secured party. An equitable solution might appear to lie in requiring mechanics to obtain a financer's permission before commencing work on the equipment. ${ }^{100}$ But since airline maintenance work is often performed far from the lender's office, mechanics are unlikely to know that a lien exists and financers most probably do not want needed repairs to await their approval. Priority should be accorded to artisans whose services enhance or preserve the value of the collateral. ${ }^{101}$

\section{RAILROADS}

Railroad rolling stock is usually financed under Philadelphia Plan Equipment Trusts. ${ }^{102}$ In the early days of railroad financing, a security device was needed to circumvent the after-acquired property clauses then contained in most mortgages. ${ }^{103}$ Since these provisions automatically encumbered railroad property as it came into the debtor's possession, financers refused to lend on the basis of newly acquired equipment. ${ }^{104}$ To promote credit, railroads offered conditional sales contracts which lodged legal title in the seller or, through his assignment, the financing party. ${ }^{105}$ However, the refusal of Pennsylvania

100. This view is frequently enunciated in motor vehicle cases. See, e.g., Champa v. Consolidated Finance Corp., 231 Ind. 580, 110 N.E.2d 289 (1953); Commercial Credit Co. v. Williams, 174 Okla. 160, 50 P.2d 141 (1935) ; City Finance Co. v. Perry, 195 Tenn. 81, 257 S.W.2d 1 (1953).

101. This policy has been adopted by the UNIFORM COMmerctal ConE § 9-310 (1957 draft), and by many courts in the more frequently litigated motor vehicle field. Theories justifying the decisions vary. Some courts consider the lender to have impliedly consented to all necessary repairs or to have made the borrower his agent to contract therefor. See, e.g., Weber Implement \& Auto Co. v. Pearson, 132 Ark. 101, 200 S.W. 273 (1917); New Britain Real Estate and Title Co. v. Collington, 102 Conn. 652, 129 Atl. 780 (1925); Guaranty Security Corp. v. Brophy, 243 Mass. 597,137 N.E. 751 (1923) ; Ruppert v. Zang, 73 N.J.L. 216, 62 Atl. 998 (Sup. Ct. 1906). Others reach the same result by finding a legislative intent to accord absolute priority to mechanics liens. See, e.g., Mortgage Securities Co. v. Pfaffmann, 177 Cal. 109, 169 Pac. 1033 (1917) ; Stebbins v. Balfour, 157 Minn. 135, 195 N.W. 773 (1923); New Hampshire Finance Co. v. LaMarche, 85 N.H. 205, 155 At1. 697 (1931) ; Crosier v. Cudihee, 85 Wash. 237, 147 Pac. 1146 (1915).

102. In 1.941, one authority estimated that $98 \%$ of all railroad equipment purchases were so financed. Dewing, Financial Policy of Corporations 207 (4th ed. 1941). Additionally, there are three other devices-the straight conditional sale, the equipment bond or "New York Plan" equipment trust, and the leaseback-none of which have much importance in railroad financing arrangements. 2 id. at 204 n.n (5th ed. 1953). For a complete discussion of the early growth and development of equipment trust financing, see Duncan, EQuipMent Obligations c. 2 (1924). Wartime developments, however, have generated some new financing arrangements. See note 108 infro.

103. Frederick, Commercial Air Transportation 459 (rev. ed. 1947). The limited period of validity given to chattel mortgages in some jurisdictions, necessitating cumbersome redrawing and refiling of instruments, also contributed to the development of the equipment trust. Billyou, Federal Railroad Equipment Legislation, 64 HARv. L. REv. 608, 609 (1951).

104. FreDERICK, op. cit. supra note 103 , at 459.

105. Davis \& Browne, Car Trusts in the United States 7 (1894). 
and Illinois, both important railroading jurisdictions, to recognize these contracts necessitated the development of an alternative instrument. ${ }^{106}$ Thus, the car lease, actually a modified conditional sale, was adopted and eventually converted into the equipment trust now successfully employed in most railroad financings. ${ }^{107}$ As the scheme is presently conceived, a corporate fiduciary takes title to the rolling stock as trustee and leases it to the railroad. Certificates representing pro rata shares of the lease are sold and the proceeds, accompanied by the railroad's down payment, are used to pay the equipment manufacturer. The railway's remaining indebtedness is discharged through annual rental payments which cover all interest, principal and trust expenses. After final payment, the lease is terminated and legal title deeded to the railroad. ${ }^{108}$

Although equipment trusts were initially insulated from conditional sale or chattel mortgage filing requirements, general railroad legislation in all states made recordation mandatory. ${ }^{100}$ Since virtually all railroads either operate on an interstate basis or exchange rolling stock with interstate carriers, multistate

106. See Murch v. Wright, 46 Ill. 487 (1868); Clow v. Woods, 5 S. \& R. 275 (Pa. 1819). Kentucky also refused to uphold such conditional sales contracts. Baldwin \& Co. v. Crow, \$6 Ky. 679, 7 S.W. 146 (18s8).

107. Early railroad financing met with a series of rebuffs at the hands of federal courts. In Heryford v. Davis, 102 U.S. 235 (1880), the court invalidated a contract intended as a car lease by deeming it a chattel mortgage void for want of recordation. See also Hart v. Barney \& Smith Mfg. Co., 7 Fed. 543 (6th Cir. 1881). Although in Harkness v. Russell, 118 U.S. 663 (1886), the Supreme Court validated a conditional sale of railroad equipment, it subsequently retrogressed in Chicago Ry. Equipment Co. v. Merchants' Bank, 136 U.S. 268, 280-83 (1890), and overturned a title retention security transaction. The flurry of litigation ceased after the passage of the state railroad equipment trust recording acts and soon these contracts were everywhere recognized as valid. Billyou, supra note 103, at 609 .

Exempted from subordination or down scaling during reorganization proceedings by both the Bankruptcy Act, 49 STAT. 922 (1935), as amended, 11 U.S.C. \$ 205(j) (1952), and the Interstate Commerce Act, 62 Stat. 163 (1948), as amended, 49 U.S.C. $\S 20 \mathrm{~b}(1)$ (1952), equipment trusts became prime security.

108. Adkins \& Billyou, Current Developments in Railroad Equipment Financing, 12 Bus. LAw. 207 (1957). Wartime pressures have engendered variations on the basic plan. The most important developments are: (1) the straight equipment lease whereby the railroad never takes title to the equipment but avoids the down payment and gains certain tax advantages; (2) conditional sales where an institutional investor buys the manufacturer's paper directly rather than have the railroad secure funds by floating equipment trust certificates through a corporate trustee; and (3) rebuilding old equipment with funds obtained through regular conditional sale or equipment trust arrangements. Id. at 209-12. The conditional sale has become particularly popular because it is not subject to ICC supervision under $\$ 20$ a of the Interstate Commerce Act, 41 Stat. 494 (1920), as amended, 49 U.S.C. $\$ 20 \mathrm{a}$ (1952). Lehigh Valley R.R. Conditional Sales Contract, 233 I.C.C. 359 (1939).

109. Starting with Ohio in 1882 and ending with Nevada in 1913, all states enacted statutory provisions relating to recordation of conditional sales and leases of railroad equipment. Duxican, Equiparent Obligations 324-29 (1924) (omission of Maryland probably inadvertent since that state also had enacted a pertinent statute, Md. Laws 1910, c. 438, p. 64). 
lien perfection difficulties attended state regulation. ${ }^{110}$ As a practical matter, railroad financers restricted filing to states in which equipment was regularly employed. ${ }^{111}$ Even this limitation, however, occasioned exorbitant costs that became intolerable as railroad activities expanded. ${ }^{112}$ Finally, in 1952, Congress added section $20 \mathrm{c}$ to the Interstate Commerce Act, which made recordation of railroad equipment liens with the ICC nationally effective. ${ }^{113}$

\section{Statutory Defects}

Although section 20c remedies most of the industry's filing problems, more extensive treatment is necessary. The section's provisions are permissive. ${ }^{114}$ Presumably, most railroad equipment liens are now filed exclusively with the ICC. Yet the act's failure to supplant state recordation systems forces careful financing institutions to examine both local and federal files. More important is the exclusion from the act of railroad fixed property encumbrances. While other carrier real property is geographically distinct and easily allocable to separate mortgages, contiguous railroad property, sometimes extending over 300 recording districts, cannot practicably be subdivided for local recordation. ${ }^{115}$ The alternative, filing a blanket mortgage in every district containing

110. For example, many states enacted conditional sales acts subsequent to their equipment trust legislation. Whether these had superseded the earlier car trust recordation acts was never resolved. Thus, many railroads complied with both statutes in such states. Billyou, supra note 103 , at 612 .

111. Id. at 611 .

112. Filing in approximately twenty-five separate offices was generally necessary at a cost of $\$ 400$ to $\$ 500$ per recordation, or a total of $\$ 10,000$ to $\$ 12,500$ for perfection alone. S. Rep. No. 1676, 82d Cong., 2 d Sess. 2 (1952).

113. 66 STAT. 724, 49 U.S.C. $§ 20 \mathrm{c}$ (1952). No litigation under $\S 20 \mathrm{c}$ has as yet arisen, all disputes having been settled at an administrative level. Immediately after the act was passed, the question arose whether firms other than railroads could record documents with the Commission. At first the ICC hesitated, then recanted and permitted recordation of any security instrument which met the statutory standards regardless of the recorder's business. Billyou, The Federal Railroad Equipment Recording Statute, 20 ICC PRAc. J. 216, 217 n.8 (1952). This position was then formalized by regulation. 17 FED. REG. 9143 (1952). However, the ICC has denied permission to record truck-trailer conditional sales contracts tied to "piggy-back" service (trucks carried on railroad cars). Interstate Commerce Commission Order, Feb. 11, 1958, Recordation of Conditional Sale Agreement and Assignment Respecting Trailers To Be Used in Piggy-Back Service.

114. The statutory language is: "Any mortgage ... may be filed . . . and such instrument . . . need not be otherwise filed . . ." 66 Star. 724, 49 U.S.C. § 20c (1952). Identical language in a bill providing for central recording of motor truck liens, S. 2031, 85th Cong., 1st Sess. (1957), was specifically criticized as being permissive by the Chairman of the ICC. Hearings, supra note 12 , at 28 . Contrast the air recordation act's phraseology that: "No conveyance ... shall be valid ... until such conveyance or other instrument is filed for recordation ...." 52 STAт. 1006 (1938), as amended, 49 U.S.C. § 523(c) (1952), United States v. United Aircraft Corp., 80 F. Supp. 52 (D. Conn. 1948) ( 503 precludes state recordation).

115. See Adkins \& Billyou, A Proposed New Form of Sectrity for the Senior Debt of Our Airlines and Railroads: Floating Charges, 12 Bus. LAw. 378, 389-90 (1957). 
railway realty, entails exorbitant fees which are usually geared to the number of words or pages in the instrument. ${ }^{116}$ Thus, centralized federal perfection for all railroad security transactions seems appropriate. Another revision of the statutory scheme should be protection of security interests during the delay between mailing and recordation as was suggested for the Civil Aeronautics Act. ${ }^{117}$

\section{TRUCKS}

Severe credit shortgages primarily attributable to multistate lien perfection difficulties frustrate expansion of the trucking industry. ${ }^{118}$ Truck financing now parallels that in the rail and air industries prior to congressional enactment of centralized filing statutes. ${ }^{119}$ When new equipment purchases are financed, conditional sales contracts, and to some extent leases, are generally preferred, while security in the form of previously acquired equipment is usual-

116. See, e.g., CaL. Gov't Code $\$ \S 27361,27361.5$; ILL. ANn. Stat. c. 115, $\$ 21$ (Supp. 1957) ; PA. Stat. ANn. tit. 21, $\$ 836$ (Supp. 1957). Some states also impose privilege taxes on recordation, e.g., OKLA. Star. Ann. tit. 68, § 1.174 (Sưpp. 1957); TENn. Code ANN. $\S 67-4102$, item $S$ (b) (Supp. 1957), which add substantially to recordation expense.

117. See notes $90-96$ supra and accompanying text. Fortunately, in the railroad field, the time lapse problem is not serious. Since most financing transactions assume major proportions, the marginal cost of recording instruments simultaneously with their execution is relatively nominal. Also, $\S 20 \mathrm{c}$ overprotects railroads against mechanics lienors. See notes 97-100 supra and accompanying text. Again, the problem is not significant in context, railroad repair work generally being done in company shops. See Henry, Ters Fascinating Railroad Business c. 17 (1942).

118. S. Rep. No. 553, 84th Cong., 1st Sess. 2-4 (1953). Institutional lenders consider a motor vehicle lien fully protected only when it has been properly filed in all 1300 United States counties. While some financers are willing to compromise on recordation limited to the truck's regular operational radius, most refuse to lend on the security of motor trucks because of the virtual impossiblity of fully perfecting these liens. S. REP. No. 701, 85th Cong., 1st Sess. 5 (1957); 101 Cong. REC 8634 (1955); Hearings, supra note 12, at 49.

The problem is not one of insufficient collateral. Trucks can be good debt security. A constant market exists; their mobility permits easy relocation to the best resale market; obsolescence does not pose a serious threat; and economical repairs minimize the depreciation factor. TAfF, Commercial Motor Transportation 101 (rev. ed. 1955). For discussion of the industry's financial position and prospects, see Regular CoMMon Carrier Conference of the American Trucking Associations, Inc., Financing the Motor CARRIER INDUSTRY (1952).

119. Recordation problems aside, existing security devices have functioned with reasonable success in the equipment financing field. Gilmore, Chattel Security: II, 57 YALE L.J. 761,782 (1948). None of the inherent defects in existing security instruments are present. For the sale is to a consumer for use, not resale; the collateral is specifically identifiable, and hence no shifting stock or floating lien problems arise; the security is usually not fully depreciated before the underlying obligation is discharged; and few after-acquired property difficulties arise because separate instruments can feasibly be executed when property later coming into the debtor's possession is to be additional collateral. Gilmore \& Axelrod, Chattel Security: I, 57 Y YLE L.J. 517, 540, 547 (1948); see also In re James, Inc., 30 F.2d 555, 556 (2d Cir. 1929) (numerous motor vehicles encumbered under three different security devices-conditional sale, chattel mortgage and trust receipt). 
ly evidenced by a chattel mortgage. ${ }^{120}$ Prevailing conflicts doctrine, however, forces financing parties to record these instruments in every state in which trucks are likely to operate. The validity of liens against a trucker's unsecured creditors, and thus his trustee in bankruptcy, nearly always depends on the lex situs-the law of the place where the chattel is located. ${ }^{121}$ Since truck liens

120. See TAFF, op. cit. supra note 118, at 103-04. Since truck mortgages, but not conditional sales contracts, must be approved by the ICC, the latter instrument has additional utility in purchase money transactions. Wilson Truck Co., 63 M.C.C. 223 (1954), Leasing arrangements, not subject to lien perfection difficulties, are also gaining popularity in purchase financing. Business Week, Jan. 24, 1953, p. 50. Approximately $40 \%$ of the e'quipment presently used by interstate carriers is leased. Hearings, supra note 12, at 29 . For discussion of this practice and rules promulgated to curb developing abuses, see $E x$ parte No. MC-43, Lease and Interchange of Vehicles by Motor Carriers, 52 M.C.C. 675 (1951), aff'd, American Trucking Associations, Inc. v. United States, 344 U.S. 298 (1953). See also Taff, Developments in the Leasing of Motor Truck Equipment, 17 So. EcoN. J. 50 (1950).

121. In the Matter of Hayes, $140 \mathrm{~F}$. Supp. 444, 447 (D. Alaska 1956); Morris Plan Co. v. Jenkins, 216 S.W.2d 160 (Mo. Ct. App. 1948) ; Burke v. First Nat'1 Bank, 197 Okla. 52, 168 P.2d 285 (1946); Restatement, Conflict of Laws $\$ \S 265,272,279$ (1934). The inconvenience of situs recordation for a multistate truck fleet is strikingly illustrated by a recent Railway Express Agency transaction. The Agency's motor vehicle program was initiated by a purchase of 3000 trucks for use in thirty-one states and the District of Columbia under a conditional sales financing arrangement. Before approving the transaction, the lender insisted that opinion of counsel be obtained on lien validity in each state. Counsel refused to give an opinion except for lender's own jurisdiction because of the complexity and diversity in state recordation laws. Consequently, opinions of local counsel in thirty-one jurisdictions had to be obtained, delaying the transaction and adding substantially to its cost. Hearings, supra note 12 , at 44 .

However, perfection is properly effected in the permanent situs jurisdiction when a chattel is temporarily elsewhere at time of contracting or when fixed relocation in a second state is contemplated. Hervey v. Rhode Island Locomotive Works, 93 U.S. 664 (1877); Enterprise Optical Mfg. Co. v. Timmer, 71 F.2d 295 (6th Cir. 1934); James Beggs \& Co. v. Bartels, 73 Conn. 132, 46 Atl. 874 (1900) ; see Johnson v. Sauerman Bros., Inc., $243 \mathrm{Ky}$. 587, 49 S.W.2d 331. (1932) (when chattel is to be relocated for a brief period in one state and then permanently in another, lien is to be perfected where it will be principally used); see also Lee, Conflict of Law's Relating to Installnent Sales, 41 MICH. L. Rev. 445, 446-47 (1942). Courts have applied the law of the permanent situs even though the contract was executed in the original situs jurisdiction before the chattel had been relocated and the parties had stipulated that the lex loci contractus-here the law of the original situs state -wias to govern. Stern v. Drew, 285 Fed. 925 (D.C. Cir. 1922) ; H. G. Craig \& Co. v. Uncas Paperboard Co., 104 Conn. 559, 133 Atl. 673 (1926); see also United States Fidelity \& Guaranty Co. v. Northwest Engineering Co., 146 Miss. 476, 112 So. 580 (1927). Contra, Rubin v. Gallagher, 294 Mich. 124, 292 N.W. 584 (1940).

Occasionally, courts have confused lex loci contractus with lex situs in holding that if the chattel is located in the jurisdiction where the contract is executed, contemplation of permanent removal is irrelevant and original situs recordation is necessary. Mergenthaler Linotype Co. v. Hull, 239 Fed. 26 (1st Cir. 1916) ; Thomas G. Jewett, Jr., Inc. v. Keystone Driller Co., 282 Mass. 469, 185 N.E. 369 (1933) (authority questioned in The Budget Plan, Inc. v. Sterling A. Orr, Inc., 334 Mass. 599, 601 n.1, 137 N.E.2d 918, 920 n.1 (1956), and overruled by the Uniform Commercial Code, Mass. Ann. Laws c. 106, § 9-103(3) (effective Oct. 1, 1958)) ; cf. Youssoupoff v. Widener, 246 N.Y. 174, 158 N.E. 64 (1927) (contract construed under laws of place of execution and original situs although permanent removal anticipated). 
are invalid unless perfected by filing, instruments must be initially recorded in those jurisdictions in which the collateral is located when the security transaction is executed. ${ }^{122}$ The possibility of contracts in states observing other rules-lex domicili, ${ }^{123}$ lex loci contractus ${ }^{124}$ or lex loci commerciendi ${ }^{125}$ may necessitate further recordation at this time. ${ }^{126}$

122. See Restatement, Conflict of Laws $\$ \$ 265,272$ (1934). Most likely, bank counsel will insist that as many vehicles as possible be assembled in one jurisdiction for original recordation purposes. This practice alleviates the complex administrative difficulties of attempting simultaneously to perfect security instruments on vehicles dispersed throughout the country, but it badly disrupts carrier operations.

123. Although judicially abandoned at the end of the nineteenth century, lex domicili or mobilia sequntur personam-the law of the owner's domicile-has been statutorily revived in four states. All four statutes provide that "If there is no law to the contrary, in the place where personal property is situated, it is deemed to follow the person of its owner, and is governed by the law of his domicile." CAL. CIV. CODE $\S 946$; IDAHo CodE ANn. $\$ 55-401$ (Supp. 1957) ; Monr. Rev. Codes ANn. $\$ 67-1101$ (Sưpp. 1957) ; N.D. REv. CODE $\S 47-0701$ (Supp. 1949). Accordingly, a carrier domiciled in any of these four states who encumbers collateral located in any of the other three has to perfect the lien at his domicile.

Generally, however, lex domicili has been repudiated in chattel security transactions. For example, compare Lally v. Holland, 31 Tenn. 396 (1852), with Newsum v. Hoffman, 124 Tenn. 369, 137 S.W. 490 (1911) ; see also Keller v. Paine, 107 N.Y. 83, 13 N.E. 635 (1887) (court noted that lex domicili was the then prevailing rule but recognized increasing applicability of lex situs in chattel cases) ; Zaphirou, The Transfer of Chatters in Prinate International Law 17-24 (1956). Contra, Southern Pac. Co. v. Kentucky, 222 U.S. 63 (1911) (ocean vessel, lacking real situs, is governed by law of owner's domicile).

124. In chattel transfer cases testing interests in the property, the law of the place where the contract is executed is applied only in Iowa and South Dakota and there apparently only when litigation involves the immediate contracting parties or third parties with knowledge of the transaction. Kusser v. Sioux City Horse \& Mule Co., 199 Iawa 200, 200 N.W. 404 (1924) ; Holt v. Mahoney, 60 S.D. 158, 244 N.W. 98 (1932); Grieme v. Robkes, 45 S.D. 480,188 N.W. 745 (1922). To the extent lex loci contractiss is so confined, recordation in the contracting state would be unnecessary to protect liens in Iowa and South Dakota since security interests are everywhere valid, absent filing, inter sese or against actually informed third parties. Martin v. Commercial Nat'l Bank, 245 U.S. 513 (1918) ; Dale v. Pattison, 234 U.S. 399, 405 (1914). While Professor Beale states that these two jurisdictions apply lex loci contractus unqualifiedly in chattel transfers, 2 Beale, Confurct of Laws 993 (1935), the Iowa and South Dakota cases he citesKusser, Holt and Griene, supra-do not seem to support his position.

125. The term lex loci commerciendi, see Note, 66 YALE L.J. 567, 577 (1957), denotes the law of the principal place of business. The rule is adopted by the Uniform Commercial Code, although qualified by a renvoi principle. For example, when litigation is initiated in a Code state, $\$ 9-103(2)$ requires courts to consult the laws, including the conflict of laws rules, of the carrier's principal place of business. Though the reference to the conficts rules-presumably lex situs-would at first seem to necessitate Code state filing, in practice it will not have this effect. For $\$ 9-103(2)$ relinquishes jurisdiction over carrier property when the home state is elsewhere. Theoretically, then, there is a reference to the home state whose conflicts rule refers back to the Code state (renvoi) which disclaims jurisdiction and again refers to the home state and so on ad infinitum. In practice, the Code's jurisdictional disclaimer and reference to the home state will cut off at that point 
Still, initial perfection is rarely sufficient, the major problems ensuing once trucks move to other jurisdictions. ${ }^{127}$ Only one state, Maine, protects foreign liens not refiled within its districts. ${ }^{128}$ Most courts refuse to uphold security

unless the home state refuses recordation. Only then will the Code state accept the reference back. See UnIform Commercial Code $\$$ 9-103, comment 6 (1957 draft).

The Code is now in force only in Pennsylvania, Pa. Stat. Ann. tit. 12A (Supp. 1957), but has been enacted in two other jurisdictions, Mass. ANw. Laws c. 106 (effective Oct. 1, 1958) ; Kentucky (effective July 1, 1960) (no official citation; Code enactment reported in 3 CCH Condit. Sale-Chat. Morr. Rep., Report Letter No. 359, April 8, 1958, p. 1). To comply with $\$ 9-103$, carriers must file liens in each of these states when trucks operate there.

Alternatively, §9-103(4) allows perfection by noting liens on a controlling certificate of title. For discussion of the titling system, see notes 137-41 infra and accompanying text. The title provision, however, was not in the $1952 \mathrm{draft}$ of the Code so Pennsylvania does not recognize the title notation method of perfection. But see note 130 infra.

126. Thus, when a truck's situs, the carrier's principal place of business or domicile and the place of contracting are located in different states, liens must be initially perfected in each of these jurisdictions.

127. Courts do not generally invalidate locally unrecorded liens perfected in other states unless the truck's transit through the foreign jurisdiction has some degree of permanence. Flora v. Julesburg Motor Co., 69 Colo. 238, 193 Pac. 545 (1920); Yellow Mfg. Acceptance Corp. v. Rogers, 235 Mo. App. 96, 142 S.W.2d 888 (1940) ; Hare \& Chase, Inc. v. Tomkinson, 129 Atl. 396 (N.J. Sup. Ct. 1925). See also In re Bowman, 28 F.2d 620 (N.D.N.Y. 1928) (intrastate removal) ; Burke v. First Nat'l Bank, 197 Okla. 52, 16S P.2d 285 (1946) (same). However, trucks operating in interstate commerce engage in regular transit through many states. Since courts have never defined the quantum of activities constituting temporary or permanent transit, institutional lenders insist that liens be refiled before or simultaneously with removal. See note 11 supra and accompanying text. This practice often hinders normal carrier operations. For example, the Railway Express Agency reports almost total inability to approve operating department requests for emergency relocation of vehicles because of lien perfection complexities. Hearings, supra note 12 , at $45-46$.

One statute has attempted to define relocation for interstate carriers. VA. CODE ANN. § 46-117 (Supp. 1956) provides that permanent use means more than three times a month. In C.I.T. Corp. v. W. J. Crosby Co., 175 Va. 16, 7 S.E.2d 107 (1940), the court interpreted the statute to require that every truck in a fleet register if combined fleet operations equal or exceed the statutory total. This decision confirmed fears that regular carrier operations would not be considered temporary and that blanket lien perfection was a practical necessity.

128. Franklin Motor Car Co. v. Hamilton, 113 Me. 63, 92 Atl. 1001 (1915), followed in Boscho, Inc. v. Knowles, 147 Me. 8, 83 A.2d 122 (1951) (conditional sales; see In re Di Pierro, 159 F. Supp. 497, 499-500 (D. Me. 1958), indicating that chattel mortgage law may be different). This doctrine will hereinafter be referred to as Rule I. Rule II will denote the view that protects foreign recorded interests when the secured party has not consented to removal, see note 129 infra, and Rule III the thesis that no locally unrecorded interests will be perfected irrespective of consent, see note 130 infra. The Connecticut legislature has enacted Rule I, effective July 1, 1959, limited to liens properly perfected on a foreign motor vehicle certificate of title. Conn. Acts 1957, No. 607, $\$ 21$ (c) (2) (A). New Jersey may also follow Rule I for foreign chattel mortgages. While no definitive state court decision exists, of. Charles T. Dougherty Co. v. Krimke, 105 N.J.L. 470, 144 At1. 617 (Ct. Err. \& App. 1929), the federal court in RFC v. Weiner, 192 F.2d 760 (2d Cir. 1951), held consent irrelevant but recognized that New Jersey policy is unclear. Unfortunately, financers cannot rely on a federal court decision but must per- 
interests perfected only in other states unless the lienor has not consented to the removal. ${ }^{129}$ Several states invalidate locally unperfected foreign liens irre-

fect in New Jersey until local policy is declared by the state supreme court. Moreover, Rule I is statutorily declared inapplicable to conditional sales contracts. See note 129 infra.

Commentators have stated that the rule obtains in other states but the authorities cited either do not support the contention or have been subsequently overruled by decision or statute. The leading articles include Carnahan, Tangible Property and the Conflict of Lazis, 2 U. CHI. L. Rev. 345,367 n.68 (1935); Lee, Conflict of Lawes Relating to Installment Sales, 41 MrcH. L. Rev. 445, 452 n.30 (1942); Leflar, Constitutional Jurisdiction Ouer Tangible Chattels, 2 Mo. L. REv. 171, 179 n.40 (1937); Stumberg, Chattel Security Transactions and the Conflict of Lawe, 27 Iowa L. Rev. 528, 538 n.37 (1942); Note, 27 GEo. L.J. 968, 970 n.12 (1939). The states supposedly adhering to Rule I according to their citations are Arizona, Arkansas, Iowa, Kansas, Maine, Maryland, Massachusetts, Minnesota, Mississippi, New Hampshire, New Jersey, Oklahoma, Vermont, Wisconsin and the federal courts. Maine and New Jersey have already been discussed. The Iowa and Minnesota cases are dicta, both courts specifically noting the removal was without consent and refusing to declare how they would decide in case of a consent removal. First Nat'l Bank v. Ripley, 204 Iowa 590, 215 N.W. 647 (1927) ; Silver v. McDonald, 172 Minn. 458, 215 N.W. 844 (1927). In Minnesota, a subsequent decision followed Rule II. See note 129 infra. Shapard v. Hynes, 104 Fed. 449 (8th Cir. 1900), generally cited as the leading case, is also dictum as was specifically recognized by one court which rejected its authority. Moore v. Keystone Driller Co., 30 Idaho 220, 223, 163 Pac. 1114 (1917). The decisions in Arizona, Arkansas, Kansas, Maryland, Massachusetts, Mississippi, New Hampshire, Oklahoma and Vermont have been overruled, see notes 129-30 infra, and the viability of the Iowa and Wisconsin decisions is problematical. For the nineteenth-century rule that interests created in one state were not divested by removal underlies the older cases. See, e.g., Weinstein v. Freyer, 93 Ala. 257, 9 So. 285 (1891). This rule, devised when chattels were relatively immovable, has declined as mobile equipment financing developed and increased opportunities for fraudulent relocation. Most courts have formulated consent doctrines to foster an equitable balance between foreign and local interests. Unless state courts have recently upheld locally unfiled liens after the lender's consent to removal, as in Maine, the most realistic assumption is that such encumberances will not be protected.

129. Rule II. ThE UNIFORM Conditional SALES ACT \& 14 (hereinafter referred to as UCSA) codifies Rule II with the modification that the vendor has ten days after learning of or consenting to the removal to refile and will be cited where applicable. States adhering to the doctrine are:

Arizona: ARIz. Code Ann. § 52-611 (Supp. 1954) (UCSA); Ragner v. General Motors Acceptance Corp., 66 Ariz. 157, 185 P.2d 525 (1947), overruling sub silentio earlier adherence to Rule I announced in Davis v. Standard Acc. Ins. Co., 35 Ariz. 392, 278 Pac. 384 (1929).

Arkansas: Chetopa State Bank v. Manes, 221 Ark. 784, 255 S.W.2d 957 (1953).

Califormia : Mercantile Acceptance Co. v. Frank, 203 Cal. 483, 265 Pac. 190 (1928).

Colorado: Mosko v. Matthews, 87 Colo. 55, 284 Pac. 1021 (1930) (Rule II followed only as to mortgages of nonmobile chattels). For the Colorado rule with respect to conditional sales contracts and motor vehicle chattel mortgages, see note 130 infra.

Consccticut: General Credit Corp. v. Rohde, 122 Conn. 100, 187 Atl. 676 (1936). This rule will be changed, effective July 1,1959, as to motor vehicles. Liens perfected on foreign certificates of title will be absolutely protected (Rule $I$ ) ; those not so perfected will be locally enforced for four months. Conn. Acts 1957, No. 607, $\$ \$ 21$ (c) (2) (A), (B).

Delaz'are: Det. Code Ann. tit. 6, $\$ 914$ (Supp. 1956) (U.CSA); Morris Plan Bank v. Terrell, 44 Del. 533, 62 A.2d 452 (1948) (chattel mortgages).

Florida: Fla. Stat. ANn. \& 319.27 (Supp. 1957), Livingston v. National Shawmut 
Bank, 62 So. $2 \mathrm{~d} 13$ (Fla. 1952), overruling the Rule III doctrine announced in Lee v. Bank, 159 Fla. 481, 32 So. 2 d 7 (1947).

Idaho: Moore v. Keystone Driller Co., supra note 128.

Illinois: The Sherer-Gillett Co. v. Long, 318 I11. 432, 149 N.E. 225 (1925). The earlier

Rule III case of Judy v. Evans, 109 I11. App. 154 (1903), was overruled by Long. Indiana: Ind. ANn. STAT. § 58-814 (Supp. 1955) (UCSA) ; Manufacturers Acceptance Corp. v. Shaver Motor Co., 120 Ind. App. 178, 89 N.E.2d 81 (1949) (chattel mortgages). Kansas: Hess-Harrington, Inc. v. State Exchange Bank, 155 Kan. 118, 122 P.2d 739 (1942), overruling earlier adherence to Rule I announced in Handley v. Harris, 48 Kan. 606, 29 Pac. 1145 (1892),

Kentucky: Herold Motorcar Co. v. Commonwealth, 216 Ky. 335, 287 S.W. 939 (1926). Kentucky recently adopted the Uniform Commercial Code, effective July 1, 1960. See note 125 supra. For the probable Code effect on consent rules, see note 130 infra (Massachusetts and Pennsylvania discussion).

Louisiana: Finance Security Co. v. Mexic, 188 So. 657 (La. Ct. App. 1939) (conditional sales); General Motors Acceptance Corp. v. Nuss, 195 La. 210, 196 So. 323 (1940), reversing the former Rule III position on chattel mortgages.

Maryland: Meyer Herson Auto Sales Co. v. Faunkhauser, 65 F.2d 655 (D.C. Cir. 1933) (applying Maryland law) ; cf. Universal Credit Co. v. Marks, 164 Md. 130, 163 Atl. 810 (1933).

Michigan: Mich. Stat. Ann. $\$ 26.929$ (1) (Supp. 1957). Michigan was formerly a Rule III state. Corbett v. Littlefield, 84 Mich. 30,47 N.W. 581 (1890). An attempt to have Corbett overruled aborted when the Michigan court split evenly, Metro-Plan, Inc. v. Kotcher-Turner, Inc., 296 Mich. 400, 296 N.W. 304 (1941), so legislative action resolved the problem.

Minnesota: Mason City Production Credit Ass'n v. Sig Ellingson \& Co., 205 Minn. 537, 286 N.W. 713 (1939). A Minnesota federal district court, however, apparently has taken a Rule I position. Personal Finance Co. v. Le Cuyer (unreported decision; case discussed in 7 PERs. F.L.Q. REP. 80 (1952)).

Missouri: Memphis Bank \& Trust Co. v. West, 260 S.W.2d 866 (Mo. Ct. App. 1953).

Montana: Walker Motor Exchange v. Lindberg, 86 Mont. 513, 284 Pac. 270 (1930).

Nebraska: Farmers \& Merchants State Bank v. Sutherlin, 93 Neb. 707, 141 N.W. 827 (1913).

Nezada: Southwest Cattle Loan Co. v. Nevada Packing Co., 53 Nev. 55, 292 Pac. 587 (1930).

New Hampshire: N.H. Rev. Stat. Ann. § $361: 14$ (Supp. 1957) (UCSA); National Bank v. Vermont Packing Co., 90 N.H. 232, 6 A.2d 176 (1939), overruling sub silentio earlier adherence to Rule I announced in Cleveland Machine Works v. Lang, 67 N.H. 348, 31. At1. 20 (1892).

Nerv Jersey: N.J. Stat. Ann. $\$ 46: 32-19$ (Supp. 1957) (UCSA). For the New Jersey position on chattel mortgages, see note 128 supra.

New Mexico: Hart v. Oliver Farm Equipment Sales Co., 37 N.M. 267, 21 P.2d 96 (1933). After partially overruling this decision, N.M. Laws 1947, c. 64, the New Mexico legislature repealed their act, N.M. Laws 1953 , c. 138, \& 21(4).

Nere York: N.Y. Pers. Prop. Law \$ 73 (UCSA); see also Guetschius v. Brightman, 245 N.Y. 186, 156 N.E. 660 (1927) (leading case; conditional sales); Edgerly v. Bush, 81. N.Y. 199 (1880) (chattel mortgages).

North Carolina: Universal Finance Co. v. Clary, 227 N.C. 247, 41 S.E.2d 760 (1947).

North Dakota: Hansboro State Bank v. Imperial Elevator Co., 46 N.D. 363, 367-68, 179 N.W. $669,670-71(1920)$.

Ohio: Kanaga v. Taylor, 7 Ohio St. 134 (1857). But see note 130 infra.

South Carolina: Adams v. Fellers, 88 S.C. 212, 70 S.E. 722 (1911).

South Dakota: S.D. CoDE $\$ 54.0214$ (Supp. 1952) (UCSA); Emerson-Brantingham Implement Co. v. Ainslie, 38 S.D. 472, 161 N.W. 1001 (1917) (chattel mortgages). 
spective of whether consent has been granted. ${ }^{130}$ In any event, since financers in interstate carrier transactions inherently acquiesce to removal, refiling is

Tentressee: Hamblen Motor Co. v. Miller \& Harle, 150 Tenn. 602, 266 S.W. 99 (1924). Tennessee initially adopted Rule III, Snyder v. Yates, 112 Tenn. 309, 79 S.W. 796 (1903), but changed to Rule II shortly thereafter, Newsum v. Hoffman, 124 Tenn. 369, 137 S.W. 490 (1911).

Texas: Bank v. Fretz, 148 Tex. 551, 226 S.W.2d 843. (1950), apparently overruling former adherence to Rule III announced in Consolidated Garage Co. v. Chambers, 111 Tex. 293, 231 S.W. 1072 (1921). But see Texas Legislative Councie, Analysis of ArTtcle 9 of the Uniforar Comarercial Cone 11 (1954) (Fretz case weakened, but did not fully overrule, prior Texas adherence to Rule III).

Vermont: Boston Law Book Co. v. Hathorn, 119 Vt. 416, 127 A.2d 120 (1956), overruling sub silentio prior adherence to Rule I announced in Barrett v. Kelly, 66 Vt. 515, 29 Atl. $S 09$ (1894).

Washington: Roedecker v. Jannah, 125 Wash. 137, 215 Pac. 364 (1923).

West Virginia: W. VA. CODE ANN. $\S 4020$ (1955) (UCSA). Chattel mortgages are discussed in note 130 infra.

Wisconsin: WIs. STAT. ANn. $\$ 122.14$ (1955) (UCSA). Chattel mortgages are discussed in note 130 infra.

Wyoming: Studebaker Bros. Co. v. Mau, 13 Wyo. 358, 80 Pac. 151 (1905).

District of Columbia: Smith's Transfer \& Storage Co. v. Reliable Stores Corp., 58 F.2d 511 (D.C. Cir. 1932).

Occasionally, a Rule II state will refuse to grant comity to the laws of a state following Rule III. Compare Union Securities Co. v. Adams, 33 Wyo. 45, 236 Pac. 513 (1925), with Hinton v. Bond Discount Co., 214 Ark. 718, 218 S.W.2d 75 (1949).

130. Rule III. The states in this group can be subdivided into two categories. The first statutorily requires their courts to protect unrecorded foreign liens for a given period of time after removal. Then, protection ceases until local recordation. Consent is not a factor. These are:

Alabama: Ala. Cade ANn. tit. 47, $\$ 123$ (Supp. 1955) (both chattel mortgages and conditional sales protected for three months after removal).

Georgia: Ga. Code Ans. \$ 67-108 (1957), cf. Armitage-Herschell Co. v. Muscogee Real Estate Co., 1.19 Ga. 552, 46 S.E. 634 (1904) (chattel mortgages protected for six months); GA. CODE ANN. § 67-1403 (1957), see Smith Motor Car Co. v. Universal Credit Co., 176 Ga. 565, 168 S.E. 18 (1933) (conditional sale protected for thirty days).

Massachusetts: Mass. Ann. Laws c. 106, $\$ 9-103$ (3) (effective Oct. 1, 1958). This statute adopts the Uniform Commercial Code which protects any unrecorded foreign lien for four months. This rule is much more liberal than similar non-Code statutory rules since it applies only to chattels which are not supposed to be removed; liens on equipment such as a motor truck which is regularly used in interstate operations are absolutely protected in the Code state after filing at the principal place of business or on a controlling certificate of title. UNIFORM COMMIERCiAL CODE $\$ \S 9-103(2)$, (4) (1957 draft). If the principal place of business disallows recordation, a reference to its conficts rules-usually lex situs-allows perfection in the Code state. See note 125 supra.

Oklahoma: OKLA. STAт. ANN. tit. 46, $\$ 58$ (Supp. 1957) (chattel mortgages protected for 120 days after removal); $i d$. tit. $60, \S 318$ (chattel mortgage rule applies to conditional sales; see Arnold v. Wittie, 99 Okla. 236, 227 Pac. 132 (1924)).

Pennsylzania: PA. Stat. AnN. tit. 12A, \$\$ 9-103(2), (3) (Supp. 1957). Pennsylvania is a Uniform Commercial Code state. See remarks under Massachusetts supra. However, Pennsylvania adopted the 1952 draft of the Code which did not provide for title certificate perfection. However, it will most likely amend its statute to conform to the current draft. The Code overruled the Rule III doctrine announced in Kaufmann \& Baer 
ordinarily necessary whenever trucks cross state lines. ${ }^{131}$ Moreover, the refusal of many states to recognize filing in advance of a truck's arrival requires

v. Monroe Motor Line Transp., Inc., 124 Pa. Super. 27, 187 Atl. 296 (1936) (even recording of foreign mortgage ineffective).

West Virginia: W. VA. CoDE ANN. § 3996 (1955) (chattel mortgages protected for thirty days). This statute overrules earlier adherence to Rule II, Cunningham v. Donelson, 110 W. Va. 331, 158 S.E. 705 (1931), as was specifically recognized by the state supreme court in Southern Finance Co. v. Zegar, 120 W. Va. 420, 198 S.E. 875 (1938).

The second category consists of states which either judicially or statutorily refuse to protect foreign liens until they have been locally perfected. These are:

Colorado: Turnbull v. Cole, 70 Colo. 364, 201 Pac. 887 (1921) (conditional sales; partially overruled in an unreported decision. See Comment, 25 Rockr Mr. L. Rev. 60 (1952)) ; Colo. Rev. Stat. ANn. \$ 13-6-32 (Supp. 1957) (limited to motor vehicle chattel mortgages not perfected on a title certificate). For rule on nonmobile chattels, see note 129 supra.

Mississippi: Mrss. Cone Ans. $\$ 870$ (1956), Patterson v. Universal Credit Corp., 204 Miss. 268, 37 So. 2 d 306 (1948).

Ohio: The Kelley Kar Co. v. Finkler, 155 Ohio St. 541, 99 N.E.2d 665 (1951) (limited to protecting local purchasers relying on a "clear" Ohio certificate of title). See Gibson v. Bolner, 165 Ohio St. 357, 135 N.E.2d 353 (1956); see also note 129 supra.

Virginia: VA. CODE ANN. \$55-99 (Supp. 1956). Virginia originally followed Rule I. Craig v. Williams, 90 Va. 500,18 S.E. 899 (1894). Then the statute, refusing protection until recordation, was drafted to cover "mortgages, deeds of trust or other encumberances." Presumably, the legislature intended to encompass conditional sales but a lower Virginia court ruled the statute inapplicable to these encumberances and pro tanto adopted Rule II. Osmond-Barringer Co. v. Hey, 7 Va. L. Reg. (N.S.) 175 (Rich. Ct. L. \& Eq. 1921). The state supreme court has avoided the question by holding that temporary use of a conditionally sold truck in Virginia did not constitute removal. C.I.T. Corp. v. Guy, 170 Va. 16, 195 S.E. 659 (1938). Constitutional attacks on the statute have been rejected. W. H. Applewhite Co. v. Etheridge, 210 N.C. 433,187 S.E. 588 (1936).

Five state courts are still uncommitted to a removal rule:

Iowa: Cf. Northern Finance Co. v. Meinhardt, 209 Iowa 895, 226 N.W. 168 (1929); First Nat'l Bank v. Ripley, 204 Iowa 590, 593, 215 N.W. 647, 649 (1927).

Oregon: Cf. Keegan v. Lenzie, 171 Ore. 194, 206-10, 135 P.2d 717, 722-23 (1943); Eli Bridge Co. v. Lachman, 124 Ore. 592, 265 Pac. 435 (1928).

Rhode Island: Cf. Ramunno v. Waterman Avenue Bakery, Inc., 78 R.I. 193, 80 A.2d 426 (1951); Goldstein v. Mack Motor Truck Co., 56 R.I. 1, 183 Atl. 136 (1936).

Utah: No case in point.

Wisconsin: For conditional sales rule, see note 129 supra. Cf. Smith v. Chicago \& N.W. Ry., 23 Wis. 267 (1868) (chattel mortgages).

131. Even if a lender contends he did not acquiesce to the removal, he will be bound. Knowledge that interstate carriage is contemplated is equivalent to consent. Robbins v. Bostian, 138 F.2d 622 (8th Cir. 1943) ; United Constr. Co. v. Milam, 124 F.2d 670 (6th Cir. 1942).

Formulated to meet problems arising from interstate automobile movements, the majority Rule II effectively balances competing interests in car removal cases. But considering the situational realities involved in multistate trucking, courts would be well advised to apply Rule I to interstate carrier fleets. See note 118 supra and accompanying text. See also Goodrich, Conflict of LAws 483, 486, 488 (3d ed. 1949) (proposing that consent never be considered a factor in chattel removal cases). A few courts have sporadically circumvented the consent element by refusing to find removal sufficiently permanent to necessitate refiling. See P. R. Smith Motor Sales Inc. v. Lay, 173 Va. 117, 3 S.E.2d 190 
elaborate arrangements for recording as vehicles enter various jurisdictions. ${ }^{132}$ For a scheduled truck line, multiple and staggered recordation is possible though extremely burdensome. ${ }^{133}$ Nonscheduled carriers, lacking an assigned route, find these machinations too impracticable to attempt. ${ }^{134}$ Finally, both multiple filing and timing problems are significantly compounded in states which require county by county ${ }^{135}$ instead of unitary recordation. ${ }^{136}$

(1939) ; cases cited note 127 supra. But since these cases did not involve vehicles engaged in regular transit through the state, they offer little comfort to interstate carriers. Moreover, the judicial trend is toward Rule III. Courts, straining to protect local bona fide purchasers and creditors from the "skip-state" purchase racket in automobiles, have resorted to many devices to avoid application of the consent dichotomy. For example, buying a car on credit in one state, the skip-state purchaser drives to another, obtains a "clear" certificate of title and resells. If Rule II were followed, the initial seller, not having consented to the removal, would prevail. Under Rule III, the thief's nonconsent removal would operate in favor of the local buyer. 2 BEale, Conflict of Laws 997-98 (1935). See also Leary, Horse and Buggy Lien Laze and Migratory Automobiles, 96 U. PA. L. Rev. 455 (1948), wherein the author cites and discusses a series of 1947 cases in which the consent rules were circumvented on technicalities. Since then, a number of cases have arisen which support Mr. Leary's thesis. See, e.g., Fruehauf Trailer Co. v. Neal, 145 F. Supp. 677 (N.D. Fla. 1956) ; Atha v. Bockius, 39 Cal. 2d 635, 248 P.2d 745 (1952) ; Seale Motor Co. v. Stone, 218 S.C. 373, 62 S.E.2d 824 (1950). And in one case, the court simply overruled its earlier adherence to Rule II, The Kelley Kar Co. v. Finkler, 155 Ohio St. 541, 99 N.E.2d 665 (1951), limiting its decision to motor vehicles, see Gibson v. Bolner, 165 Ohio St. 357, 135 N.E.2d 353 (1956). See also Lee v. Bank, 159 Fla. 481, 32 So. $2 d 7$ (1947), discussed in note 129 supra. Unfortunately, judicial attempts to control interstate automobile frauds have shifted emphasis to the harshest possible rule and thus redound unfavorably to the trucking industry.

132. Hearings, supra note 12, at 49 ; see also Stumberg, Chattel Security Transactions and the Confict of Lazes, 27 Iowa L. Rev. 528, 546 (1942); WamManN, Truck ConsPANY Financing SO (unpublished thesis 1946). One state even refuses to recognize recordation of liens encumbering chattels frequently, though not continuously, located in the jurisdiction. In Vervaris v. Egan, 226 Ill. App. 500 (1922), the court accorded a local attaching creditor priority over a previously recorded chattel mortgage. The basis of the decision was that the truck had acquired sufficient situs to be attached but not enough to validate local recordation. See also Kaufmann \& Baer v. Monroe Motor Line Transp., Inc, 124 Pa. Super. 27, 187 Atl. 296 (1936) (Pennsylvania's policy against recording foreign chattel mortgages extends to foreign liens; local perfection not permitted). This decision has been overruled by Pennsylvania's adoption of the Uniform Commercial Code. See PA. Stat. Ann. tit. 12A, § 1-201(37) (Supp. 1957).

133. See Uniform Conimercial Code, Further Recommendations of the ENlarged Editorial Board for Amendment of Text and Answers to Certain Critictsms 180-81. (1955).

134. See Uniforar Commercial Code $\$ 9-103$, comment 3 (1952 draft).

135. See, e.g., N.Y. Pers. Prop. Law \$ 74; Wash. Rev. Code ANn. $\$ 61.04 .090$ (1957) ; Wyo. CoMrp. Stat. Ann. $\$ 59-109$ (Supp. 1957). Moreover, in many states the law is unclear whether county by county recordation is required, WAHMANN, TRUCK Company Frnancting 80 (unpublished thesis 1946), thereby forcing additional filings.

136. Smith v. Simmons, 35 Ga. App. 427, 133 S.E. 312 (1926) ; Bailey v. Godfrey, 54 III. 507 (1870); Hauseman Motor Co. v. Napierella, 223 Ky. 433, 3 S.W.2d 1084 (1928). Even this system, however, engenders confusion. For while chattel mortgages need only be filed at one place in the state, that location will often differ from the one designated 
The mechanics of filing combine with complex and diverse recording prerequisities to make multistate lien perfection virtually impossible. In most jurisdictions, ordinary filing requirements have been supplemented or replaced by motor vehicle certificate of title laws. ${ }^{137}$ Twenty-one states, the District of Columbia and Alaska have eliminated recordation and substituted title certificate notation as the exclusive means of perfecting security interests in motor vehicles. ${ }^{138}$ Semi-exclusive statutes in seven states require both filing and title notation. ${ }^{139}$ In seven other jurisdictions, title notation, though permitted, does

for recording conditional sales or equipment leases. See Gilmore, The Secured Transactions Article of the Commercial Code, 16 Law \& Contmar. Prob. 27, 32 (1951).

137. See Townsend, The Case of the Mysterious Accessory, 16 Law \& ConTEnip. Prob. 197 (1951). For Code treatment of title certificates, see UNIFORM COAMMERCiAl CODE $\$ \$ 9-302(3),(4)$ (1957 draft) ; id. \$ 9-302(2) and comments thereto (1952 draft).

138. ArIz. Code AnN. § 66-231(f) (Supp. 1954); ARK. Stat. ANn. $\$ 75-161$ (b) (1957); Cal. Vehicle Code $\$ 198$; Colo. Rev. Stat. ANn. $\$ 13-6-19$ (Supp. 1957); Del. Code Ann. tit. 21, § 2335 (Supp. 1956) ; Fla. Stat. Ann. § 319.15 (1958); Idaho Code Ann. \& 49-414 (1957); Iowa Code AnN. \$ 321.50 (Supp. 1957) ; La. Rev. Stat. AnN. \& 32-710 (Supp. 1957); Mont. Rev. Codes Ann. \$ 53-110(b) (Supp. 1957); Neb. Rev. Stat. AnN. \& 60-110 (1952) ; Nev. Rev. Stat. \$ 482.450 (1956) ; N.M. Stat. AnN. \$ 64-5-2(b) (1953); Ohio Rev. Code And. $\$ 4505.13$ (Page Supp. 1957); Ore. Rev. Stat. Ann. \$ 86-390(3) (1957); PA. Stat. Ann. tit. 75, § 33(b) (Supp. 1957) ; S.D. Code $\$ 44.0203$ (1) (Supp. 1952) ; Tenn. Code AnN. § 59-327(b) (Supp. 1957); Tex. PEN. Code ANN. art. 1436-1, $\$ 44$ (Supp. 1957) (statute ambiguous but interpreted as exclusive in Commercial Credit Co. v. American Mfg. Co., 155 S.W.2d 834 (Tex. Ct. Civ. App. 1941)) ; Uram Code Ans. § 41-1-87 (Supp. 1957); VA. Code ANn. § 46-71 (Supp. 1956) ; D.C. CoDE ANN. $\$ 40-702$ (Supp. 1957); Alaska Sess. Laws 1951, c. 124, $\$ 7(6)$. Pennsylvania is included although the statutory provision is ambiguous. In Kaufmann \& Baer v. Monroe Motor Line Transp., Inc., 124 Pa. Super. 27, 187 Atl. 296 (1936), the court refused to recognize title perfection as valid. This decision was sharply criticized but followed in Taplinger v. Northwestern Nat'1 Bank, 101 F.2d 274 (3d Cir. 1938). Then, Commercial Banking Corp. v. Active Loan Co., 135 Pa. Super. 124, 4 A.2d 616 (1938), apparently overruled Kaufmann \& Baer. See In re Berlin, 147 F.2d 491 (3d Cir. 1945); In re Miller, 107 F. Supp. 1006 (E.D. Pa. 1952), both recognizing exclusive title perfection as valid on the strength of Commercial Banking Corp. Contra, In re Bair, $49 \mathrm{~F}$. Supp. 56 (M.D. Pa. 1943), adhering to Kaufmam \& Baer. The Pennsylvania supreme court has not yet ruled on the question.

Geographically, the statutes are concentrated in the West and Southwest, where truck traffic is relatively light. Of the commercially important eastern states, only Ohio and probably Pennsylvania have exclusive statutes.

139. Kan. Gen. Stat. Ann. \& 8-135 (c) (2) (Supp. 1957), General Motors Acceptance Corp. v. Davis, 169 Kan. 220, 218 P.2d 181 (1950) ; Mrch. STat. Ann. \& 9.1497 (Supp. 1957), Nelson v. Viergiver, 230 Mich. 38, 42, 203 N.W. 164, 165 (1925); Mo. Ann. Stat. $\$ 443.480$ (Supp. 1957), Kansas City Automobile Auction Co. v. Overall, 241 Mo. App. 280, 238 S.W.2d 446 (1951) (applies to nonpurchase money security interests only; see note 140 infra) ; N.J. Stat. ANN. § 39:10-11 (c) (Supp. 1957) ; N.D. Laws 1957, No. 161 (mortgagee may retain possession of certificate in lieu of title notation); WasH. REv. CODE ANn. \$\$ 46.12.030(2), 46.12.050, 46.12.170 (1957), Merchants Rating \& Adjustment Co. v. Skaug, 4 Wash. 2d 46, 102 P.2d 227 (1940) ; Wyo. Comrp. Stat. Ann. § 60-208(f) (Supp. 1957) (Nonpurchase money security interests must be recorded and notated concurrently through depositing security instruments with the county clerk. Purchase money security interests cannot be perfected on a title certificate. See Note, 11 Wyo. L.J. 47, $48-49$ (1956)). 
not constitute perfection. ${ }^{140}$ Within each of these categories, moreover, marked variances in notation prerequisites exist. ${ }^{141}$ Lien perfection aside, certification is required by all title states as a condition of registration. ${ }^{142}$ While the cost of titling is nominal, ${ }^{143}$ the concomitant registration fees and highway use taxes prerequisite to local operation are substantial. ${ }^{144}$ In the interest of equitable distribution of revenues, a "gentlemens agreement" among states permits carriers to allocate vehicles for certification so that each interstate truck need only

140. IND. ANN. Stat. $\S 547-2501,51-501(\mathrm{k})$ (Supp. 1955) (chattel mortgages specifically included under regular recording act; see Note, 25 IND. L.J. 337 (1950)); MD. ANn. CODE art. 66r/2, $\$ 28$ (c) (1957), In re Rosen, 23 F.2d 687 (D. Md. 1928); N.C. Gen. Stat. Anv. \& $20-57$ (Supp. 1957), Carolina Discount Corp. v. Landis Motor Co., 190 N.C. 157, 129 S.E. 414 (1925) ; OKLA. Stat. Ann. tit. 47, \$ 23.3 (Supp. 1957), KingGodfrey, Inc. v. Rogers, 157 Okla. 216, 11 P.2d 935 (1932); W. VA. CoDE ANN. \$ 1721 (130) (Supp. 1957); Wrs. Stat. Ann. $\$ 85.01$ (3) (a) (1955), Commercial Credit Corp. v. Schneider, 265 Wis. 264, 61. N.W.2d 499 (1953).

Whether Georgia should be classified as a certificate of title or simply a registration state is debatable. The statute, GA. CODE ANN. $\$ \$ 68-206$ to -208 (1957), provides for a certificate of title to act as indicia of both title and registration. In all other states, registration functions are discharged through licensing not certification. The Georgia certificate is not delivered to the secured party as it is in many states. Moreover, Georgia is the only state requiring annual renewal of the certificate.

In the remaining thirteen states-Alabama, Connecticut, Hlinois, Kentucky, Maine, Massachusetts, Minnesota, Mississippi, New Hampshire, New York, Rhode Island, South Carolina and Vermont-and Hawaii, chattel mortgage and conditional sales recording statutes still apply. Missouri and Wyoming, not listed above, should also be included in this category with respect to purchase money security interests. Mo. ANN. STAT. $\S 443.480$ (Supp. 1957) specifically excludes purchase money chattel mortgages from title notation provisions. Id. $\$ 428.100$ provides that conditional sales contracts must be filed as chattel mortgages. See Butler County Finance Co. v. Prince, 231 S.W.2d 834 (Mo. Ct. App. 1950) (local filing only method of perfecting vehicle purchase money security interests). The Wyoming act is unclear, but a state periodical reports that local practice is recordation only. See note 139 supra.

Connecticut will become an exclusive title state on July 1, 1959. Conn. Acts 1957, No. $607, \$ \$ 21$ (a), 48 .

Illinois until recently was a nonexclusive title state but its act has just been repealed. III. Laws 1957, No. 802 (effective Jan. 1, 1958).

141. Regular Common Carrier Conference of the American Trucking Assoctations, Inc., Financing the Motor Carrier Industry 41 (1952); Richter, A Uniform Motor Velicle Certificate of Title Law-A New Attempt, Bus. Law., July 1953, pp. 6, 8. Consequently, financers still follow their pre title law practice of obtaining opinions by local counsel before lending against a multistate truck fleet. See note 121 supra.

142. See, e.g., Del. Code Ann. tit. 21, 2301 (Supp. 1956); Mp. Ann. Code art. $661 / 2, \S 24$ (a) (1957); WASH. Rev. Code ANn. $\$ 46.12 .020$ (1957).

143. See, e.g., ARK. Stat. ANn. $\$ 75-183$ (Supp. 1957) (50\& for issuing titles; same for noting liens); LA. REv. Stat. ANN. $\$ 32: 728$ (Supp. 1957) ( $\$ 1.00$ for issuing titles; same for noting liens); N.J. Stat. Ann. $\$ \$ 39: 10-11$ (A), (C) (Supp. 1957) ( $\$ 1.50$ for issuance; $\$ 2.00$ for notation).

144. See TAFF, op. cit. supra note 118, at 566-67; see also Capitol Greyhound Lines v. Brice, 339 U.S. 542, 562 (1950) (summary of Supreme Court litigation involving stateimposed taxes on interstate motor carriers). 
be titled in one jurisdiction. ${ }^{145}$ Yet no complimentary agreement exists for recognition of liens noted on certificates issued by a foreign state. And while retitling would be exorbitantly expensive, filing may not be sufficient to safeguard encumbrances in semi-exclusive states nor be possible in exclusive title jurisdictions. ${ }^{146}$ In the twenty-seven states in which recordation is still indispensable, filing laws drafted to govern local encumbrancing of relatively immovable chattels thwart the needs of a highly mobile industry. ${ }^{147}$ Some statutes antedate the invention of the automobile ;148 all contain involved and divergent recording requirements. For example, most states demand that security instru-

145. Letter from Walter D. Malcolm, Esq., Member of the Massachusetts Bar and Chairman of the American Bar Association Committee on the Proposed Uniform Commercial Code, to Professor Grant Gilmore, Nov. 12, 1957, copy on file in Yale Law Library (based on a limited sampling of carrier practices). The reciprocity arrangements usually allocate registrations according to a proportional approximation of average annual miles hauled in each state by a carrier to total average annual mileage. Since states do not title vehicles unless they are registered in the jurisdiction, title' splitting is a necessary concomitant of the reciprocity agreement. Letter from Walter D. Malcolm, Esq., supra; see TAFF, op. cit. supra note 118, at 571 (reporting that twenty-six states authorize their officials to enter into any form of reciprocity agreement, e.g., IowA CODE ANN. \$ 321.56(2) (Supp. 1957), and that in most other states circumscribed authority exists).

146. That the question is unresolved is disclosed by several commentators, Leary, supra note 131, at 474; Wahmann, Truck Company Financing 75 (unpublished thesis 1946), and answers to inquiries sent to interested parties, letter from J. B. Wahmann to the Yale Law Joumal, April 21, 1958, on file in Yale Law Library; letter from Homer Kripke, General Counsel for CIT Credit Corp., to the Yale Law Journal, April 7, 1958, on file in Yale Law Library. Only one state, see FLA. STAT. ANN. $\$ 319.27$ (3) (b) (1958), has a definite provision allowing filing of foreign liens with the Motor Vehicle Commissioner. Other exclusive title statutes usually provide that notation shall be the only means of perfecting a security instrument on a vehicle registered under the state's laws. See, e.g., CAL. VEHICLE CODE $\S 198$. While this language can be construed as requiring notation of encumbrances only for trucks registered and titled in the state, two courts have held that recordation is insufficient, retitling and notation mandatory. In C.I.T. Corp. v. W. J. Crosby \& Co., 175 Va. 16, 7 S.E.2d 107 (1940), the court ruled that an entire fleet must reregister and retitle in Virginia if any combination of trucks operates there more than three times a month. And in Universal C.I.T. Credit Corp. v. Vogt, 86 N.W.2d 771, 777 (Neb. 1957), the court held that notation on a local title certificate was the exclusive method of perfecting a lien even though the truck was not registered by the state.

The Uniform Motor Veniche Certificate of Title ANd Anti-Theft Act $\$ 20$ (c) indicates a possible solution. Under this act, liens on any equipment used in interstate transportation are locally valid if perfected on a foreign title certificate. Unfortunately, no comparable provision exists in any existing title statute, and the Uniform Act has been enacted in only one state, Connecticut, effective July 1, 1959. Conn. Acts 1957, No. 607.

147. "Chattel mortgage law and conditional sales law are what they are, not because any one in his right mind ever thought that such a body of law made sense, but as a result of a long process of tinkering to make late-medieval legal forms workable in an industrialized society." Gilmore, Chattel Security: II, 57 Yale L.J. 761,775 (1948).

148. See, e.g., ARK. Star. ANn. \$\$ 51-1001 to -1009 (Supp. 1957) (basic sections enacted between 1875 and 1893) ; Iowa CoDE ANN. $\$ \S 556.1$-.28 (Supp. 1957) (derived from an 1851 statute) ; MrNN. Stat. ANN. $\$ \$ 511.01-.32$ (Supp. 1957) (basic sections derived from an 1897 act). See, generally, Leary, supra note 131. 
ments be acknowledged, the requirements varying sharply ;49 $^{140}$ in a few, verification, notarization or attestation is added or substituted. ${ }^{150}$ Accompanying good faith or value affidavits, unnecessary in some jurisdictions, ${ }^{151}$ are exacted in many. ${ }^{162}$ Compliance with such varied requirements would be difficult enough if allowed before trucks entered each jurisdiction. But when financing parties are forced to attempt on-route perfection, errors are, for all practical purposes, unavoidable. ${ }^{153}$

Truck liens unperfected in any on-route jurisdictions are not only invalid in those states but may be avoidable in bankruptcy. Failure to observe the filing or notation prerequisites of a state in which encumbered vehicles operate permits attaching creditors to apply trucks to their own claims. ${ }^{154}$ Should the trucker go into bankruptcy, in which event the validity of security interests becomes crucial, section 70 (c) of the Bankruptcy Act gives the trustee title to all property "upon which a creditor of the bankrupt could have obtained a lien ... at the date of bankruptcy ... whether or not such a creditor actually exists." 165 Accordingly, the mere presence of a vehicle in a jurisdiction whose perfection requirements have not been satisfied when a bankruptcy petition is filed would cause invalidation of the instrument. What may be a small risk for an individual truck lien is significantly enhanced when entire fleets are mortgaged. Use of one instrument, moreover, might magnify the effects of

149. See, e.g., Ir. Ann. Stat. c. 95, § 2 (Supp. 1957) ; Miss. Code Ann. § 857 (1957); Ore. Rev. Stat. Anv. $\$ 86.320$ (1957). Acknowledgment requirements and relevant cases are collected in Annot., 25 A.L.R.2d 1124 (1952).

150. E.g., UTA CODE ANN. § 9-1-1 (Supp. 1957). Some states have wisely repealed these formalities. E.g., ME. Rev. Star. AnN. c. 178, § 1. (Supp. 1957). For cases in which minor deviations from formal requirements have caused invalidation of liens, see Noyes v. Bank, 206 Cal. 266, 274 Pac. 68 (1929) (acknowledgment) ; First Nat'1 Bank v. Baker, 62 Ill. App. 154 (1896) (same); Cunningham v. Cureton, 96 Ga. 489, 23 S.E. 420 (1895) (attestation); Consumers Credit Co. v. Manifold, 65 Idaho 238, 142 P.2d 150 (1943) (notarization).

151. E.g., Ind. Ann. Stat. $\$ 51-508$ (Supp. 1955) ; Utah Laws, 1945, c. 18, 11 (now Utar Code Ann. \$ 9-1-1 (Supp. 1957)), amending UTAa Code Ann. \$. 13-0-1(2) (19+3).

152. E.g., Md. Ann. Code art. 21, $\$ 30$ (1957) ; Mrch. Stat. Ann. $\$ 26.929$ (Supp. 1957) ; WASH. Rev. Code ANN. $\$ 61.04 .020$ (1957).

153. See notes 131-36 supra and accompanying text. Moreover, most jurisdictions impose lien refiling requirements, adding greatly to the chance of error. For a complete summary of all state lien refiling requirements, see $1 \& 2 \mathrm{CCH}$ Condit. SALE-CHAT. Mort. REP. (all states) $\{180$ (conditional sales), $\llbracket 480$ (chattel mortgages). In addition, some states prescribe a definite period beyond which liens are unenforceable against third parties. S. Rep. No. 553, 84th Cong., 1st Sess. 3 (1955). Presumably, mortgages must be reexecuted as well as refiled in these jurisdictions.

154. If all requirements are not met, the instrument is deemed unrecorded. Consumers Credit Co. v. Manifold, 65 Idaho 238, 142 P.2d 150 (1943) ; People v. Burns, 161 Mich. 169,125 N.W. 740 (1910). And if it is unrecorded, attaching creditors prevail. Elk Creek Lumber Co. v. Hamby, 84 F.2d 144, 146 (4th Cir. 1936) ; Berlein v. Eddy, 89 Fla. 484, 487, 104 So. 780, 781 (1925) ; Peter Schuttler Co. v. Gunther, 222 Mich. 430, 435, 192 N.W. 661,663 (1923).

155. 30 StAT. 565 (1898), as amended, 11 U.S.C. $\$ 110(c)$ (1952). 
bankruptcy invalidation. To avoid the necessity of refiling liens in the same state every time different trucks enter, a single document is frequently employed. ${ }^{156}$ However, a fleet mortgage invalid as to one truck when bankruptcy ensues might be entirely voidable under the doctrine of Moore v. Bay. ${ }^{167}$ In $B a y$, a mortgage on several chattels securing a $\$ 10,000$ obligation was mistakenly filed in the wrong county. Before the error was corrected, the mortgagor incurred several minor debts. Under the local law, the mortgage would have been void as against these creditors but valid against obligations of the bankrupt arising after filing in the proper county. ${ }^{158}$ Nevertheless, the Supreme Court, relying on principles applicable to section $70(\mathrm{c})$, held that the trustee in bankruptcy could avoid the whole mortgage and distribute the property it secured to general creditors. ${ }^{159}$ Arguably, the instant problem is distinguishable from $B a y$ in that trucks located in protected states are not reachable by creditors, real or hypothetical, residing in vulnerable jurisdictions. On the other hand, since the creditors in Bay could not reach the full amount of collateral eventually freed by the Court, the case seems sufficiently analogous to make fleet security of doubtful validity in bankruptcy when the filing demands of an on-route state have not been met.

Even if perfection requirements are everywhere observed, liens may be similarly invalidated when filing is delayed. Statutes in at least eight states permit a gap creditor-one acquiring a claim between the execution and per-

156. See note 132 supra and accompanying text.

157. 284 U.S. 4 (1931).

158. Compare Ruggles v. Cannedy, 127 Cal. 290, 53 Pac. 911 (1899), with United Bank \& Trust Co. v. Powers, 89 Cal. App. 690, 265 Pac. 403 (1928).

159. Thus, if a $\$ 100,000$ mortgage is superior to all interests except a $\$ 100$ claim, the security interest is set aside for the claims of unsecured creditors which, but for bankruptcy, would be subordinate. Zamore v. Goldblatt, 194 F.2d 933 (2d Cir. 1952) ; 4 CoLLIER, BANKRUPTCY If 70.95 (14th ed. 1942). The Bay decision provoked harsh criticism, Scott, The Meaning of the Provisions for Recordation of a Transfer as Applicable to Preference Under the Bankruptcy Act and a Critique of the Decision of the United States Supreme Court in the Case of Moore v. Bay, 18 VA. L. REv. 249, 265-69 (1932), and equally vigorous defense, Note, 9 AM. Bankr. Rev. 23 (1932). See also Schwartz, Moore vs. Bay-Should Its Rule Be Abolished?, 60 CoM. L.J. 67 (1955). It was widely noted. See Moore \& Countryman, Debtors' and Creditors' Rights $888 \mathrm{n} .1$ (1951) (collecting citations).

The bankruptcy courts have enthusiastically enforced the doctrine. See cases collected in 4 COLLIER, op. cit. supra. They have generally been unsympathetic to assertions that application of Bay is inequitable. See, e.g., Friedman v. Sterling Refrigerator Co., 104 F.2d 837, 841 (4th Cir. 1939) (the lender is at fault if the lien is imperfect; therefore he has no cause for complaint). Moreover, there is the "part-bad, all-bad" doctrine of Brown v. Leo, 12 F.2d 350 ( $2 \mathrm{~d}$ Cir. 1926), in which the court held that a mortgage on chattels and realty is totally void if the chattel lien alone is invalid. Brown was applied to a multichattel transaction in Arbury v. Kocher, 18 F.2d 588 (W.D.N.Y. 1927). Though decided as an extension of Benedict v. Ratner, 268 U.S. 353 (1925) (for discussion see notes 76$78,80,84-87$ supra and accompanying text), Brown has not been cited in recent decisions in that area. However, it could be revivified in the Benedict context or used as an extension of Bay. Consequently, it should be considered in planning secured credit arrangements. 
fection of a security interest-to defeat that interest, even after its perfection, by obtaining a judicial lien. ${ }^{160}$ Under the rule of Constance v. Harvey, section 70 (c) arms the trustee in bankruptcy with the rights of a hypothetical gap creditor. ${ }^{161}$ In the context of truck financing, the critical gap occurs between a vehicle's arrival in a Constance state and perfection within that jurisdiction. ${ }^{102}$ Located in all areas of the country, states in which Constance is oper-

160. The cases so holding are:

California: Ruggles v. Cannedy, 127 Cal. 290, 53 Pac. 911 (1899), applied in National Bank v. Moore, 247 Fed. 913 (9th Cir. 1918) (bankruptcy).

liaine: Production Credit Ass'n v. Kent, 143 Me. 145, 56 A.2d 631 (1948); see In re Di Pierro, 159 F. Supp. 497, 499-500 (D. Me. 1958) (chattel mortgage only; not conditional sale).

Maryland: Thomas Roberts \& Co. v. Rabinson, 141 Md. 37, 118 At1. 198 (1922), applied in Friedman v. Sterling Refrigerator Co., supra note 159 (bankruptcy) (state case ambiguous; federal case clear).

Vichigan: Ransom \& Randolph Co. v. Moore, 272 Mich. 31, 261 N.W. 128 (1935), applied in $I n r c$ Cotter, 113 F. Supp. 859 (E.D. Mich. 1953) (bankruptcy).

Missouri: Pearson v. Lafferty, 197 Mo. App. 123, 193 S.W. 40 (1917), applied in Mercantile Trust Co. v. Kahn, 203 F.2d 449 (8th Cir. 1953) (bankruptcy).

New York: Karst v. Gane, 136 N.Y. 316, 32 N.E. 1073 (1893), applied in Constance v. Harvey, 215 F.2d 571 (2d Cir. 1954) (bankruptcy) (chattel mortgage only; not conditional sale).

North Dakota: Union Nat'1 Bank v. Oium, 3 N.D. 193, 200-01, 54 N.W. 1034, 1036 (1S92), followed, Lakota Mercantile Co. v. Balsley, 60 N.D. 768, 236 N.W. 631 (1931).

South Dakota: Hollenbeck v. Louden, 35 S.D. 320, 152 N.W. 116 (1915).

In Barber v. Reina Nash Motor Co., 72 Wyo. 65, 81, 260 P.2d 928, 933 (1953), the court cited cases from two additional jurisdictions, Kentucky and Wisconsin, as following this delay-in-perfection doctrine. The Kentucky case, Wicks Bros. v. McConnell, $102 \mathrm{Ky} .434$, 43 S.W. 205 (1S97), is apparently no longer followed in that state. A 1916 amendment to the Kentucky statutes, now Kr. Rev. Stat. ANN. $\$ 382.270$ (1955), was interpreted by the Kentucky Court of Appeals to preclude such a result, Smith v. Holland, 298 Ky. 598, 607,183 S.W.2d 647, 651 (1944). The Wisconsin case, Sanger v. Guenther, 73 Wis. 354, 41 N.W. 436 (1889), does not rest on delayed filing but fraud. The holding is apparently limited to cases in which the mortgagee fraudulently delays filing at the mortgagor's request. Then, subsequent filing does not defeat previously accrued rights of gaip creditors. No Wisconsin case exists defining whether the same rule applies to innocently delayed recordations.

161. 215 F.2d 571 (2d Cir. 1954). The Second Circuit has reaffirmed its stand, Conti v. Volper, 229 F.2d 317 (2d Cir. 1956); and Constance has been followed by the Ninth Circuit, England v. Sanderson, 236 F.2d 641 (9th Cir. 1956). Contra, In re Di Pierro, supra note 160, at 498-99 n.2 (criticizing Constance). For a discussion of Constance, see Comment, 67 Yale L.J. 402, $412-13$ n.37 (1958). See also National Bankruptcy Conference, Summary of Proceedings, 1956 Annual Meeting, Resolution No. 36 (condemning Constance and suggesting legislative revision); Seligson, Annual Survey of Anerican Laze, Bankruptcy, 30 N.Y.U.L. REv. 558, 559-62 (1955) (criticizing Constance); Seligson, Creditar' Rights, 32 N.Y.U.L. REv. 708, 722-23 (1957) (same).

162. Of the eight Constance states, seven follow Rule II on protection of liens after collateral removal. See note 129 supra. Since consent is inherent in interstate truck financing, see note 131 supra, perfection will be necessary in these jurisdictions. The eighth Constance state, Maine, follows Rule I. See note 128 supra. To the extent that Maine so 
ative are likely to be on-route for most interstate vehicles. ${ }^{163}$ And gaps seem inevitable since mortgages cannot be filed before a truck's arrival. ${ }^{104}$ More important, the likelihood that one vehicle will be situated in a Constance state when a bankruptcy petition is filed combines with the doctrine of Moore $v$. $B a y$ to threaten the validity of an entire fleet obligation. ${ }^{165}$

The obvious inability of interstate truck lines to offer unimpeachable security has impelled interested parties to seek congressional action. Proposed legislation has followed two patterns: central recordation with the Interstate Commerce Commission ${ }^{166}$ and nationally effective perfection through compliance with the laws of the state in which a carrier principally conducts business. ${ }^{137}$ Although truckers favor central recording, ${ }^{168}$ ICC opposition has forced them to promote the state perfection solution. ${ }^{169}$ The most recent bill adopting this approach, S. 375 , has obtained Senate approval and will soon be considered by the House. ${ }^{170}$ Its ultimate enactment would undoubtedly aid truck financing. Yet the bill, and the approach, seem defective.

protects security interests in removed trucks, application of Constance would seem to depend on whether the truck was regularly operated in, rather than removed to, the state. However, Maine may distinguish between chattel mortgages and conditional sales for purposes of Rule I protection. Compare Production Credit Ass'n v. Kent, 143 Me. 145, 56 A.2d 631 (1948), ruith Boscho, Inc. v. Knowles, 147 Me. 8, 83 A.2d 122 (1951); see In re Di Pierro, 159 F. Supp. 497 (D. Me. 1958).

163. See note 160 supra.

164. See note 132 supra and accompanying text.

165. See notes 157-59 supra and accompanying text.

Under another interpretation of Constance, entire fleet obligations will be jeopardized when a truck has at any time been in a Constance state. According to that interpretation, $\$ 70$ (c) gives the trustee the rights of a hypothetical creditor who obtained a lien, instead of merely extending credit, between execution and perfection of a security interest. See MOORE, DeBtoRs' AND CREDITORS' Rights 656 n.3 (1955). Hypothetically, then, a creditor could have attached a vehicle whenever it was present, but not promptly recorded, in a Constance state. His subsequent hypothetical transformation of that attachment into a judgment lien could conceivably meet $\S 70$ (c)'s requirement of obtaining a lien at the date of bankruptcy. Application of Moore v. Bay would then avoid the entire fleet mortgage.

166. S. 768, 83d Cong., 1st Sess. (1953) ; S. 711, 84th Cong., 1st Sess. (1955); S. 2031, 85th Cong., 1st Sess. (1957). None were reported out of committee. A copy of S. 2031 is reprinted in Hearings, supra note 12, at 4-5.

167. S. 3185, 83d Cong., 1st Sess. (1953), reported out of committee, S. REP. No. 1461, 83d Cong., 2d Sess. (1954); S. 1966, 84th Cong., 1st Sess. (1955), reported out of committee, S. REp. No. 553, 84th Cong., 1st Sess. (1955) ; S. 375, 85th Cong., 1st Sess. (1957), reported out of committee, S. REP. No. 701, 85th Cong., 1st Sess. (1957). For a full discussion and text of S. 375, see notes 170-88 infra and accompanying text.

168. S. REP. No. 701, 85th Cong., 1st Sess. 5 (1957) ; Hearings, supra note 12, at 45, $48,52-53,58$.

169. Id. at $30,54,55$.

170. 103 Cong. Rec. 12327-28 (daily ed. Aug. 5, 1957), referred to the House Committee on Interstate and Foreign Commerce, 103 Cong. REC. 12554 (daily ed. Aug. 6, 1957). The bill provides:

"(a) As used in this section the term 'purchaser' means any mortgagor, lessee, bailee, buyer, or person holding a motor vehicle under a title retaining contract, mortgage, 


\section{Defects in Proposed Legislation}

S. 375 fails to take full cognizance of present title certificate systems and, indeed, truck operations. ${ }^{171}$ The recent state trend toward certificates of title laws can, to a large extent, be ascribed to a reappraisal of recording functions. ${ }^{172}$ Filing requirements are traditionally justified as a means of protecting creditors who may see chattels in a debtor's possession and rely on them for ultimate satisfaction or actually demand them as security. ${ }^{173}$ Rather than conduct burdensome and often costly record searches, however, both trade and institutional creditors typically depend on their own evaluation of a debtor's honesty and continued solvency. ${ }^{174}$ Complementing this practice, the notation

lease agreement, bailment, trust indenture, or other instrument having the effect thereof.

"(b) Any mortgage, lease, equipment trust agreement, conditional sale agreement, or other instrument evidencing the lease, conditional sale, or bailment of one or more motor vehicles owned by, or the use and possession of which has by such instrument been transferred to, a motor, rail, express, or water carrier subject to any provision of this Act [Interstate Commerce Act] shall be valid and enforcible without filing or recording in any State against any person to the same extent that such instrument would be enforcible against such person if the filing and recording statutes of such State, if any, applicable to such documents had been complied with, if

"(1) such instrument has been recorded or filed in the State in which the purchaser resides, or if a corporation or other business legal entity has its principal place of business, and/or

"(2) such instrument is valid or enforcible against creditors of the purchaser and against subsequent purchasers from the first purchaser named in such instrument in the State in which the purchaser resides, or if a corporation or other business legal entity has its principal place of business."

Both of S. 375's predecessors, see note 167 supra, obtained Senate approval but were never reported out of committee in the House, Hearings, supra note 12 , at 50 , apparently because the House, like the trucking industry, favors central recording, id. at 56. See also 101 Cong. Rec. 8634 (1955) ; 100 CoNg. Rec. 7384 (1954).

171. See notes $137-40$ supra and accompanying text.

172. Leary, Horse and Buggy Lien Law and Migratory Automobiles, 96 U. PA. L. REv. 455, 458-61 (1948); Townsend, The Case of the Mysterious Accessory, 16 LAw \& Contexip. Prob. 197, 201-04 (1951).

173. See In re Noel, 137 Fed. 694, 701 (D. Md. 1905) ("The object of the recording of conveyances is to prevent the hardship resulting to creditors and purchasers from the existence of secret conveyances, not disclosed by the public records, of property of which the grantor remains the ostensible owner"). See also Central Acceptance Corp. v. Lynch, 58 F.2d 915 (6th Cir. 1932); In re Bennett, 264 Fed. 533 (W.D. Mo. 1920) (collecting authorities).

174. See Barrett v. Bank of the Manhattan Co., 218 F.2d 763, 766 (2d Cir. 1954) ("it is most improbable that a third person dealing with the buyer would think it important to consult the records ...."). See also Hanna, The Extension of Public Recordation, 31 Colun. L. Rev. 617, 633-34 (1931) ; Koessler, Assignments of Acconnts Receivable, 33 CALIF. L. Rev. 40, 41. (1945). But see testimony of representative of unsecured creditors arguing that filing of chattel mortgages is desirable to prevent credit extensions on strength of apparent ownership. NEw YoRk LAw Revision Commission, Assignasents of Accounts Recervable 258-59 (1946). 
requirement of title certificate laws permits easy determination of a debtor's interest in motor vehicles. ${ }^{175}$ Certificates are either carried by vehicles or in the possession of financing parties. Creditors are, therefore, warned of lien existence by the certificate itself or the trucker's inability to produce it. To encourage reliance on a title's information, states generally refuse to grant certificates unless owners avouch that their vehicles are not titled in another jurisdiction. ${ }^{176}$ An obvious weakness of the system is that double titling can still be secured by dishonest applicants with a view toward financing two loans on the same vehicle. S. 375, though recognizing only those liens perfected in a carrier's home state, may increase this possibility. Approximately half the interstate trucks in operation are certificated in jurisdictions other than the principal place of business. ${ }^{177}$ To this extent, compliance with S. 375 would necessitate retitling in home states. Since retitling would require reregistration, one objective of S. 375-elimination of high perfection costs-would be frustrated. ${ }^{178}$ Moreover, the existence of other certificates, in fact useless for perfection or disclosure purposes, might prove deceptive to a trucker's creditors. And insolvent debtors, now possibly restrained by the expense or inconvenience of purchasing second titles, may be more tempted to double financing, once forced to possess two certificates.

Alternatively, retitling might not be allowed, nor recording be sufficient, in exclusive or semi-exclusive jurisdictions. ${ }^{179}$ Honest truckers located in these states but registered in others would then be unable to offer security. ${ }^{180}$ Recognizing that S. 375 had combined with interstate compacts to create an impossible situation, courts might hold that truck liens noted on other state's titles could be perfected in title certificate home states by recordation with ordinary chattel mortgages. Even this view, however, would offer only a partial solution. Liens cannot be filed in most states unless the vehicle is engaged in

175. Reliance on title certificates issued by exclusive or semi-exclusive jurisdictions is standard commercial practice. Memorandum From Walter Malcolm, Esq. and Robert Haydock, Jr., Esq. to the Members of the American Law Institute Subcommittee on Article 9 of the Uniform Commercial Code, August 16, 1957, copy on file in Yale Law Library.

176. Letter from Walter D. Malcolm, Esq., supra note 145 . If retitling is allowed, the usual requirement is that all liens on the first title be disclosed and notated on the second. See, e.g., Cal. Vericle Code $\$ 146.1$ (c).

177. The statistical estimate was made by Messrs. Walter Malcolm, Esq., and Robert Haydock, Jr., Esq., in Memorandum, supra note 175.

178. See notes $142-44$ supra and accompanying text.

179. See note 146 supra and accompanying text.

180. For example, a few states refuse to retitle a vehicle already titled elsewhere even though the vehicle is reregistered. See, c.g., Wyo. Conr. Stat. Ann. $\$$ 60-203 (Supp. 1957). And a few states have held that liens cannot be perfected by local filing but a certificate of title must instead be procured. Universal C.I.T. Credit Co. v. Vogt, 86 N.W.2d 771, 777 (Neb. 1957) ; C.I.T. Corp. v. W. J. Crosby \& Co., 175 Va. 16, 7 S.E.2d 107 (1940). Should the Wyoming court enunciate a similar decision, carriers having their principal place of business in Wyoming would be unable to secure the home state title certificates necessary to perfect liens under S. 375 . 
regular transit within the jurisdiction. ${ }^{181}$ Since in many multistate trucking concerns certain vehicles are rarely operated in the carrier's home state, financing would still be curtailed. Should courts again compensate for S. 375 by allowing recordation in the home state despite a vehicle's absence, out-of-state creditors would be forced to check distant files to determine the existence of outstanding encumbrances. And to the extent that protecting creditor reliance on specific chattels is a goal of commercial law, eliminating the notice factor of title certificates would be commercially retrogressive. ${ }^{182}$

Another commercial objective-certainty-would also be subverted by the bill. Whether the filing of liens on specific trucks constituted perfection in a titling home state would often be resolved in other forums. Until every certificate of title jurisdiction decided these issues, the efficacy of many transactions would remain problematical. Eventually, states might themselves enhance the utility of S. 375 by enacting complementary legislation. For example, all titling states could deny certificates to vehicles of carriers principally conducting businesses in other jurisdictions yet, pursuant to interstate agree- ment, continue registration. ${ }^{183}$ Concomitantly, these states could certificate all trucks belonging to companies primarily situated within their borders despite lack of local registration. Nevertheless, federal legislation thus dependent on statutory amendment in twenty-eight states at best rests on an insecure foundation. ${ }^{184}$ Apart from its failure to cope with title certificate laws, S. 375 would grant national perfection to many security interests evidenced neither by filing

181. See, e.g., Cal. Vehicle Code $\S 143.5$; see also Wammann, Truck Conspany Financing 76-77 (unpublished thesis 1946).

182. S. 375 may also pose constitutional questions. Clearly, a state statute providing that perfection within the state is perfection everywhere cannot be extraterritorially enforced. See, e.g., Morris Plan Co. v. Jenkins, 216 S.W.2d 160, 164 (Mo. Ct. App. 1.948); Comment, Validity of Judgments Refusing Recognition to Chattel Mortgages Recorded in Another State, 37 Y ALE L.J. 966 (1928). Consequently, by making compliance with the home state's recording requirements nationally effective, S. 375 may involve a delegation of power issue. If delegation were found, the bill might neverthele'ss be upheld on convenience, cf. United States v. Sharpnack, 355 U.S. 286, 293-94 (1958), or full faith and credit grounds, see, generally, Jackson, Full Faith and Credit-The Lawyer's Clause of the Constitution, 45 Colum. L. Rev. 1 (1945). More likely, however, the constitutional question would be avoided by a finding that the bill did not adopt prospective state regulation but only that existing at the time of its enactment. See United States v. Paul, 31 U.S. (6 Pet.) 141 (1832). Congressional adoption of present, as opposed to future, state laws is more properly classified as an incorporation by reference than a delegation. Resolution of the constitutional problem in this fashion, however, would only serve to heighten the commercial undesirability of the bill. For as states changed their recording systems, Congress would have to adopt the alterations before national perfection could be achieved under the new procedure. Gaps would inevitably arise between state renovation and congressional readoption. During these periods, of course, the status of truck liens would at best be unclear.

183. See note 145 supra.

184. At present, there are twenty-one exclusive title, see note 138 supra, and seven semi-exclusive title states, see note 139 supra. 
nor notation. Most truck financing occurs when vehicles are purchased. ${ }^{185}$ The security device employed, the conditional sale, is deemed perfected in many nonexclusive and nontitling jurisdictions absent recordation. ${ }^{186}$ True, creditors seldom examine files. ${ }^{187}$ But removing every opportunity to determine the existence of nationally perfected liens seems a commercially dangerous solution. ${ }^{188}$

A revision of S. 375, introduced by truckers to safeguard the title certificate system, contains similar defects. ${ }^{189}$ The key section of the revision provides that, once a motor vehicle lien is noted on a title certificate, nationwide perfection of the security interest is governed by the laws of the issuing jurisdiction. On the other hand, liens on noncertificated vehicles are considered na-

185. Regular Common Carrier Conference of the American Trucking Associations, Inc., Financing the Motor Carrier Industry 40 (1952). See also Tafr, Conmerctal Motor Transportation 98-102 (rev. ed. 1955) ; Wahmann, Truck Conpany Financing 67 (unpublished thesis 1946).

186. States not requiring filing of conditional sales contracts are: Arkansas, California, Florida, Illinois, Indiana, Louisiana, Massachusetts, Michigan, Mississippi, Nevada, Oregon, Rhode Island, Tennessee and Utah. Summary prepared from 1 \& $2 \mathrm{CCH}$ CondrT. SALE-Chat. Mort. Rep. (all states) II 150.

In Florida and Mississippi, conditional sales contracts running longer than a specified statutory term must be filed. FLA. STAT. ANN. $\$ 726.09$ (Supp. 1957) (two years) ; Miss. CODE ANN. $\$ 266$ (1956) (three years). In Massachusetts, conditional sales will be recordable when the Uniform Commercial Code comes into effect. Mass. Ans. Laws c. 106, $\$ \S 9-401,9-403$ (effective Oct. 1, 1958). Louisiana does not recognize locally initiated conditional sales contracts. See Finance Security Co. v. Mexic, 188 So. 657 (La. Ct. App. 1939).

187. See note 174 supra and accompanying text.

188. S. 375 may contain a latent Constance problem. See notes 160-65 supra and accompanying text. The bill provides that liens "shall be valid and enforcible without filing or recording in any State against any person to the same extent that such instrument would be enforcible against such person if the filing and recording statutes of such state, if any, applicable to such documents had been complied with . ..." (Emphasis added.) In a Constance jurisdiction, the recording laws can be "complied with" despite a gap after execution. The effect of recordation is to perfect only against creditors whose claims arose subsequent to perfection, not those obtaining claims during the gap. Thus, under S. 375, filing in the home state within some safe time after execution may be deemed "compliance" with the laws of a Constance jurisdiction, although the "to the same extent" language plus the existence of a gap may cause invalidation in bankruptcy.

189. The relevant sections are:

"(b) If a motor vehicle subject to a security interest is covered by a certificate of title issued under a statute of a jurisdiction which requires or permits indication on a certificate of title of such security interest in a motor vehicle, then the perfection of the security interest is governed by the law of the jurisdiction which issued the certificate and the security interest is perfected in all jurisdictions against all general creditors and subsequent lien creditors of and all subsequent purchasers from the debtor carrier if the security interest is indicated on the certificate.

“(c) In all cases not governed by subparagraph (b), the perfection of a security interest is governed by the law of the home state and the security interest is perfected 
tionally perfected if recorded in the carrier's home jurisdiction, or when filing is not there permitted, if perfected "under the law (including the conflict of laws rules) of the home state."190 The first provision would obviate the necessity to acquire several titles, for perfection purposes, on each interstate truck. Yet the problem of double titling for fraudulent objectives would be unrelieved. ${ }^{101}$ More important, by necessitating recourse to the conflicts rule of a carrier's home state, presumably lex situs, the latter provision would often occasion the very multistate perfection difficulties which the revision was designed to remedy. ${ }^{192}$ Since the gentleman's agreement among states pertains to registration as well as titling, interstate trucks are frequently registered in nontitle jurisdictions. Should the home state of a carrier using such noncertificated vehicles not allow recordation, liens would be tested by the laws of any state in which the trucks were operated. The likelihood that a need for perfection in every on-route jurisdiction would thus be restored is high. ${ }^{193}$ Con-

in all jurisdictions as to all general creditors and subsequent lien creditors of and all subsequent purchasers from the debtor carrier if

"(1) there has been a public filing or recording of or with respect to the security interest in the home state, or

"(2) the security interest has been perfected as to general creditors and subsequent lien creditors under the law (including the conflict of laws rules) of the home State.

"(d) Nothing in this Section shall prohibit the holder of a security interest from perfecting such interest in accordance with the laws of the several states and the District of Columbia."

Permission to quote received in Letter from James F. Fort, Esq., Assistant to the General Counsel, American Trucking Associations, Inc., to the Yale Law Journal, May 7, 1958, on file in Yale Law Library.

190. Revision § (c) (2), note 189 supra.

191. Moreover, the revision, relying on interstate agreements under which trucks engaged in multistate operations are titled in only one state, see note 145 supra and accompanying text, presumes the existence of a single title. But multiple titling, though not prevalent, certainly exists. Letter from Homer Kripke, General Counsel for CIT Credit Corp., to the Yale Law Journal, April 7, 1958, on file in Yale Law Library. The possibility of existing second titles is enhanced by the requirements of states such as Nebraska and Virginia which make retitling prerequisite to lien perfection. See note 146 supra.

Moreover, some states do not adhere to reciprocity agreements but insist that all operating vehicles be registered. TAFF, op. cit. supra note 185 , at 565-66. And trucks registered in a state must be retitled there. See note 145 supra. See also State v. Teeslink, 177 Kan. 268, 278 P.2d 591 (1955) (lower court held sua sponte that the State Reciprocity Commission had exceeded its constitutional authority in allowing foreign carriers to operate in Kansas without reregistering and retitling; remanded for further hearing).

192. Revision § (c) (2), supra note 189.

193. The revision also raises the same constitutional doubts as $S$. 375 . See note 182 supra. Moreover, neither S. 375 nor its revision adequately defines principal place of business. Possible tests include: (1) greatest quantum of activities, (2) location of executive offices, (3) principal terminal and (4) central accounting. The absence of a specific standard would impair needed predictability as well as permit courts to upset commercial reliance on the controlling effect of one jurisdiction. See, e.g., In re Riverdale Productions, Inc., 107 F. Supp. 87 (S.D.N.Y. 1952) ; cf. Comment, 67 Y ALE L.J. 402 (1958). The 
ditional sales contracts, used to encumber a large percentage of trucks, cannot be filed in many jurisdictions. ${ }^{194}$ And other security interests on out-of-state vehicles may not be recordable in the carrier's home state. ${ }^{195}$

By far the greatest shortcoming of the revision is its last provision: "Nothing in this Section shall prohibit the holder of a security interest from perfecting such interest in accordance with the laws of the several states and the District of Columbia." 196 Carriers could, therefore, satisfy the revision by noting title certificates, recording liens in their home states or filing in any jurisdiction in which vehicles are located. ${ }^{197}$ As a result, neither lenders nor third parties could safely rely on title certificates or home state files. Unless willing or able to examine the records and titles of every on-route jurisdiction, financers would either have to depend on borrowers' warranties of clear title or refrain from financing-alternatives representing no progress from the existing commercial quagmire.

Unavoidable weaknesses in both S. 375 and its revision demonstrate the need for a centralized perfection system. The ultimate objectives to be achieved in the field of truck financing are simply stated. For interstate carriers and institutional lenders, the near impossible task of perfecting liens in many states should be remedied, the cost decreased. For unsecured creditors as well as subsequent financers, some method should be established which permits convenient determination of outstanding liens. Absent complete reciprocity among states, certificate of title laws cannot fully accommodate interstate transactions. Retitling, sometimes essential for perfection purposes, proves costly to carrier and financer or allows the procuring of a fraudulent second title which jeopardizes all classes of creditors. Significantly, incorporation of state law by federal statute not only fails to cure the defects of the title certificate system but heightens the undesirability of outmoded filing doctrines. Some combina-

principal place of business test employed by the Uniform Commercial Code was attacked on grounds of vagueness, New YoRK LAw Revision CoMmission, STUdY of THE UNIFORM Commerctal Cone, Article Nine 92-93 (1955), though the Code draftsmen defended its use, Uniform Comarercial Code, Further Recommendations of the Enlarged Editorial Board for Amendinents of Text and Ansivers to Certain Criticisms 179 (1955). In doubtful cases, liens could be filed in all possible "home states," but not without restoring double filing and double titling problems. Even if principal place of business were adequately defined, neither S. 375 nor the revision provides for relocation contingencies. Liens perfected in the home state would presumably be invalid after a carrier moved unless refiling and/or retitling were immediately effected.

Both S. 375 and the revision are inapplicable to liens on the interstate trucks of noncarrier owners. Approximately $40 \%$ of the interstate fleet is comprised of leased equipment. Hearings, supra note 12 , at 29 . Since many lessors are simply rental agencies, not carriers, their financing problems would be unrelieved by either bill.

194. See note 186 supra and accompanying text.

195. Lack of "permanent" situs would preclude recordation jurisdiction. See notes 127, 181 supra and accompanying text.

196. Revision $\$$ (d), supra note 189.

197. See notes 121-22, 137-40 supra and accompanying text. 
tion of troublesome factors-retitling, ${ }^{198}$ double financing, ${ }^{199}$ removal refiling ${ }^{200}$ and perfection of liens filed in only one state or entirely unrecorded ${ }^{201}$ -must, of necessity, obtain under such legislation. Conversely, the ultimate values of title certification could be realized, and the flaws eliminated, if the responsibility were federally assumed. Indeed, a federal recording and title certification bureau could resolve the problems confronting ship, aircraft and railroad equipment financing as well as those which plague the trucking industry.

\section{Federal Recording Bureau}

Experience derived from years of state experimentation with perfection methods indicates the functions of the proposed agency. Security instruments should be filed so that interested parties may discover their terms. ${ }^{202}$ Also, federal certificates of title should be issued to permit easy ascertainment of ownership and lien existence. ${ }^{203}$ Encumbrances both recorded with the bureau and noted on title certificates should be considered perfected throughout the

198. See notes 177-80 supra and accompanying text.

199. See note 176 supra and accompanying and following text.

200. See notes 192-95 supra and accompanying text.

201. See notes 186-88 supra and accompanying text.

202. Filing should not be required for possessory liens. As most courts recognize, possession itself is sufficient notice of third party interests. See Petition of Chattanooga Sav. Bank, 261 Fed. 116 (6th Cir. 1919) (pledge) ; Marrs v. Barbeau, 146 N.E.2d 353 (Mass. 1957) (attachment). A specific exception is suggested to avoid results of cases like In re Boston, 84 F. Supp. 594 (N.D. Tex. 1949), where the court, narrowly interpreting the Texas Certificate of Title Act, held that recordation of a mechanics lien by a repairman in possession of the chattel was necessary.

203. Federal titling will facilitate determination of interests for parties geographically distant from the central bureau. A titling system is already in effect for both ships, Rev. STAт. \$§ 4159-61 (1875), as amended, 46 U.S.C. $\$ \S 29-31$ (1952) (vessel certificate of enrollment), and airplanes, 52 STAT. 1005 (1938), as amended, 49 U.S.C. $\$ 521$ (1952) (aircraft certificate of registration). Documentary lien indorsement is required by the Ship Mortgage Act, 41 Stat. 1000-01 (1920), 46 U.S.C. $\$ \$ 922(a)(1),(a)(2)$, (d) (1952), and is authorized by the Civil Aeronautics Act, 52 STAT. 1006 (1938), as amended, 49 U.S.C. $\$ 523(\mathrm{~g})$ (1952), though the CAA has declined to perform this function, 14 C.F.R. $\$ 501 \mathrm{n} .1$ (Supp. 1957). Titling may be unnecessary for railroad cars since, in effect, they carry their own titles, all being plainly marked with the owners name. Moreover, railroad rolling stock transactions are relatively few in number and substantial in amount so that the risk of bona fide purchasers or creditors being misled is negligible. The jurisdictional extension will involve only federal pre-emption of motor truck titling. The proposal is in line with current ICC policy favoring federal titling of all motor vehicles. See statement of the Hon. Owen Clarke, Chairman of the ICC, Hearings, supra note 12, at 29. All nonpossessory liens should be eligible for perfection on the federal title certificate. Purchase money and nonpurchase money security interests should not be differentiated as was done under the Missouri and Wyoming title statutes. See note 140 supra. Junior liens should also be perfectable, in contrast to New Jersey law, N.J. STAT. ANN. \& 39:10-11 (Supp. 1957), which permits only first liens to be noted. See National City Bank v. Del Sordo, 16 N.J. 530, 109 A.2d 631 (1954). If the title is to be relied on by third parties in lieu of a record search, it must reveal all outstanding obligations. 
country. ${ }^{204}$ Double titling would thus be precluded, ${ }^{205}$ perfection immeasurably simplified and notice made readily available. ${ }^{206}$ To date, other recommendations for federal perfection have presupposed management by the Interstate Commerce Commission. That performing perfection functions for millions of vehicles would unduly burden this agency is documented by ICC opposition to such plans. ${ }^{207}$ On the other hand, the creation of a new filing administration

204. A federal certificate of title system would, of course, entail the maintenance of title as well as security interest records. Leaving the function of recording title transfers to the states would force purchasers of secondhand trucks to examine both state and federal files. See Hearings, supra note 12, at 19,29. A federal act can easily be adapted from the recently promulgated Uniform Motor Vehicle Certificate of Title and Anti-Theft Act, 9B UNIFORM LAws ANN. 239-73 (1957), which includes all necessary provisions.

205. See text following note 178 supra. Under the state system, no coordinated supervision over title issuance exists. Consequently, dishonest debtors can and do obtain fraudulent second titles. See Leary, Horse and Buggy Lien Law and Migratory Automobiles, 96 U. PA. L. Rev. 455 (1948). But under a federal system, unitary control could easily prevent issuance of second titles. Moreover, federal titling would facilitate curbing the "duplicate title" racket. Many states presently issue "clear" duplicates when the applicant avers that the "lost" title showed no liens. Leary, supra at 476. Administrative procedures whereby duplicate titles are distinctively marked as such with a warning that the vehicle may be subject to undisclosed liens should effectively curb this swindle. See UNrForm Motor Vehicle Certificate of Titie and Anti-Theft Act § 13(a).

206. State objections to federal pre-emption of the titling function may be forthcoming. Some state highway taxes are geared to title issuance. See, e.g., Mo. ANv. Cope art. $661 / 2, \S 29$ (1957) (tax equal to $2 \%$ of fair market value imposed on all vehicles engaged in interstate commerce as prerequisite to certification). Since motor vehicle registration laws are not pre-empted by the proposed federal statute, taxes presently imposed upon title issuance could be levied instead when a vehicle is registered. Secondly, states obtain revenues from issuing title certificates and recording security instruments. However, these amounts are relatively minor in the state budget and are used mainly to defray clerical costs. See note 143 supra. Since the clerical function is to be eliminated, only a slight real revenue loss, if any, will occur. Nontitle states may have to make a more substantial adjustment. Their recording fees are much higher, sometimes $\$ 1$ for every $\$ 100$ face value of the instrument recorded. Hearings, supra note 12, at 49. To the extent recording fees are actually revenue measures, loss will have to be recompensed by a highway tax. Public interest in improving trucking facilities should override any inconvenience attending minor shifts in state taxing structures.

Present confusion derives from diversities among state systems. See Richter, A Uniform Motor Vehicle Certificate of Title Law-A New Attempt, Bus. Law., July 1953, p. 6. That states are not prepared to remedy the situation is evidenced by the history of the Uniform Motor Vehicle Certificate of Title and Anti-Theft Law, 9B Unrform Laws ANn. 239-73. The Commissioners urged adoption of the act to preclude threatened federal legislation. Prefatory Note, $i d$. at 235. Yet only one state, Connecticut, has enacted the uniform statute. Ibid. Its rejection in other jurisdictions is noted in Report of the Subcommittee on Commercial Laws, Motor Vehicle Certificate of Title Act, 11 Bus. Law. 4 (1956).

207. Hearings, supra note 12 , at 19-20,30, 55. At present, 586,000 vehicles regularly operate in interstate commerce. $I d$. at 29 . This figure is computed by including tractortrailer units as one vehicle. Since liens are often obtained separately against each unit, a more relevant count would be over 1,000,000 vehicles. Ibid. Of the 9,000,000 more commercial trucks and busses which do not qualify as interstate common or contract carriers, 
would not only meet this objection but, by relieving the existing perfection duties of the ICC, CAA and Customs Bureau, curb needless duplication of administrative expense. ${ }^{208}$ Costs now incurred by 126 federal offices for separately recording aircraft, railroad and ship encumbrances could be minimized through operation of a central bureau. ${ }^{209}$ Moreover, a consolidated system would expedite blanket financing for companies which operate integrated ship, airline, railroad or trucking facilities as well as make credit investigation more convenient.

$i b i d$, presumably many engage in some interstate operations, thus substantially increasing the total to be governed by a federal agency.

An independent bureau could also assume future governmental recordation functions which would otherwise have to be channeled to existing administrative bodies. For example, see Note, 67 YaLE L.J. 504, 513 n.42 (1958), proposing federal recording for livestock chattel mortgages. See also Adkins \& Billyou, Developments in Commercial Aircraft Equipment Financing, 13 Bus. Law. 199, 204 (1958), urging federal recording for liens on all aircraft fixed property.

Locating the bureau in Washington may not be necessary. Since the District of Columbia area is becoming congested, a geographically central location, such as Kansas City or Chicago, might be preferable. See Hearings, supra note 12, at 55-56.

208. The introduction of modernized recording techniques would both simplify operations and further reduce costs. For example, machines have been developed which can read documents. Van Deusen, The Coming Victory Over Paper, Fortune, Oct. 1955, pp. 130, 199. Avoiding the necessity for transferring documentary material to punch cards, this innovation in automatic clerical machines should soon be out of the experimental stage and ready for use in an operation such as the one proposed. See also Time, March 17, 1958, p. 61. Another workable device to reduce record storage and handling costs is microfilming. See, generally, De Sola, Microfilaring cc. 1, 3 (1944). The cost is negligible. One firm estimates that $4000 \mathrm{~S} / 2^{\prime \prime} \times 11^{\prime \prime}$ documents can be microfilmed for $\$ 4.15$ including processing and handling. Letter from Recordak Corp. to the Yale Law Journal, Jan. 16, 1958, on file in Yale Law Library. In fact, microfilming has already been put to use in at least one state recording system. See Fra. Stat. Ann. \$ 318.09 (1958).

209. In addition to one office operated by the CAA and one by the ICC, 124 filing divisions are maintained in U.S. "home ports" for recordation of ship mortgages. See notes 35-36 supra and accompanying text. The total number of home ports is obtained from 19 C.F.R. \$ 1.1 at 6-12 (Supp. 1957), which lists all United States ports. An asterisk before the name of any port indicates that it may issue marine documents. $I d$. at $5 \mathrm{n} .3$. Only ports of documentation can be home ports. Letter from the Bureau of Customs to the Yale Law Journal, Feb. 26, 1958, on file in Yale Law Library. A count of the asterisked ports totals 119 plus 5 ports added by 19 C.F.R. $\$ 1.1$ at 5 n.5 (Supp. 1957), or 124 in all.

Elimination of home port recordation will necessitate repealing 41 STAT. 1002-03 (1920), 46 U.S.C. $\$ \$ 925-27$ (1952). For a summary of all change's to be made in the present Mortgage Act, see note 217 infra. The only function properly left to the Collector of Customs would be documentary indorsement. Since vessels cannot be cleared for sailing unless documents are on board ship, customs office indorsement avoids the delay inherent in forwarding papers to a central office. Moreover, each Collector should indorse documents only for home port vessels. The existing system, 41 SrAT. 1001 (1920), 46 U.S.C. $\$ 922$ (d) (1952), requiring indorsement to be made in any port upon telegraphed or mailed instructions from the home port's Customs Collector, and refusing clearance until all formalities are completed, should be abandoned. Instead, preferred status should be granted until the vessel returns to its home port, to avoid both clearance delays and increased possibility of error inherent in existing law. 
With the establishment of a new federal bureau, perfection law should be modernized to reflect contemporary goals. Primarily, meaningless formalities now contained in most state and federal recording statutes should be abolished. Recordation serves principally to provide notice of lien existence to interested third parties and to prevent fraudulent backdating of security transfers. 210 Good faith affidavits, notary public seals, acknowledgments and similar prerequisites are unrelated to either function. ${ }^{211}$ More generally, a commercial good faith standard of reasonableness should underlie all requirements. Instruments promptly sent to the bureau for recordation should be deemed perfected as of the date of their execution. ${ }^{212}$ In comparable fashion, temporary filing without registration certificate indorsement should be allowed during a ship's voyage, to remain effective for a reasonable time after the encumbered vessel's return to its home port. ${ }^{213}$ The judicial rule invalidating defective filing should also be replaced by the reasonableness standard so that errors which are not seriously misleading will not preclude lien perfection. ${ }^{214}$ When, through government fault, instruments are misfiled or liens not noted on title certificates, the secured lender should be fully protected. Other parties detrimentally relying on erroneous files or title certificate notation may be compensated out of risk distribution funds derived from recordation fees. ${ }^{215}$ Finally, renewal refil-

210. See Hanna, Some Unsolved Problems Under Section 60A of the Bankruptcy Act, 43 Colum. L. Rev. 58, 70 (1943) ; authorities cited note 174 supra. See also Howard v. McPhail, 37 R.I. 21, 24, 91 At1. 12, 14 (1.914). But see Comment, 67 Yale L.J. 402, 432 n.105 (1958).

211. See notes 149-52 supra and accompanying text.

212. When a good faith filing is rejected and refiled within a reasonable time, protection should also commence from the date of original execution. This provision will avoid such problems as the one raised by Kerley Chemical Corp. v. Colboch, 145 Cal. App. 2d 509, 302 P.2d 621 (1956), discussed in text accompanying notes 91-92 supra.

213. See notes $40-43$ supra and accompanying text.

214. This approach is adopted by the UnIForM COMrMercial CODE $\S 9-402(5)$ (1957 draft). Moreover, serious partial errors should result only in partial invalidation.

215. Reimbursement should be limited to the loss suffered from actual reliance. If the secured party causes the error, the risk distribution fund should not be available. Instead, all creditors detrimentally relying on files should have a superior claim against the collateral. Here, too, parties not checking records before extending credit should not benefit from the mistake. Only where detrimental reliance is proven would the unsecured creditor's rights become superior to those of the secured lender. Mistakes should seldom occur if modernized recording techniques are employed. See note 208 supra. Potential government error can be further reduced by not imposing record search responsibilities on the bureau, Both the CAA and ICC have adopted this practice. The ICC so provides by regulation. 49 C.F.R. $\$ 57.5$ (d) (Supp. 1957). The CAA follows the same procedure although no specific regulation to that effect has been promulgated. See Hearings, supra note 12, at 30 . Both agencies keep their files properly indexed and open to public inspection, a custom which should be continued under the proposed system. In the few cases in which information cannot be obtained from an equipment document, or geographical distance prevents a personal record search, actual notice would probably be obtainable from a private agency. Fees should be relatively nominal, especially when present cost of state or customs office file checking is considered.

At present, litigation is required to determine whether the creditor or third party bears 
ing should be required to prevent the accumulation of outdated records, though, contrary to most acts, ${ }^{210}$ a filed instrument should remain valid for the term of the loan it evidences. ${ }^{217}$

the initial loss. Theoretically, the loser may then sue the state but rarely does so because of judicial reluctance to impose liability. See, e.g., Boscho, Inc. v. Knowles, $147 \mathrm{Me.} \mathrm{8,} 83$ A.2d 122 (1951); Securities Credit Corp. v. Pindell, 153 Neb. 298, 44 N.W.2d 501. (1950). The Ship Mortgage Act has a section permitting suit against the Collector of Customs for misfeasance in recording or indorsing documents. 41 STAT. 1003 (1920), 46 U.S.C. § 941 (c) (1952). Yet to date, the section has never been tested. Gilarore \& Black 588-89. Instead of wasteful litigation, equitable distribution of risk seems more appropriate. Although the bureau's negligence would cause the loss, financial responsibility seems better placed on the carriers than the taxpayers.

Various systems presently in effect are directly analogous. Notably, the Torrens system of land registration creates a fund for the benefit of non-negligent claimants. See, e.g., Minn. Stat. Ann. $\$ 508.76$ (Supp. 1957). For general discussion, see Cushman, Torrens Titles and Title Insurance, 85 U. PA. L. Rev. 589, 600-02 (1937). Under the French droit administratif, government failure to record a lien apparently constitutes a faute de service for which the citizen is entitled to compensation by the state. See Berthelemy, The 'Conseil D'Etat' in France, 12 J. CoMrp. LEG. \& INT'z L. (3d ser.) 23, 30-32 (1930).

216. See, e.g., UnIform Commercial Code $\$ 9-403(2)$ (1957 draft) (five years); Uniform Conditional Sales Act § 11 (three years); Kan. Gen. Stat. Ann. § 58-303 (Supp. 1957) (two years). See also note 153 supra.

217. The statute should provide that the bureau retain the instrument for its stated term and for a specified time thereafter, to be destroyed absent timely request for renewal. Refiling within this period would revalidate the instrument for any requested term.

In sum, the proposed law would have the following effect on present statutes. It would repeal the Ship Mortgage Act's recordation provisions, $41 \cdot$ STAT. $1000-03$ (1920), 46 U.S.C. $\S \S$ 922-23, 925-27 (1952), the Civil Aeronautics Act lien recordation section, 52 STAт. 1006 (1938), as amended, 49 U.S.C. $\$ 523$ (1952), and the Interstate Commerce Act's railroad equipment lien perfection provision, 66 STAT. 724, 49 U.S.C. $\$ 20 \mathrm{c}$ (1952). However, only the following sections should not be re-embodied in the proposed act:

Ship Mortgage Act \$ 922(a) (3) (good faith affidavit provision), for reasons stated in note 43 supra.

Ship Mortgage Act $\S 922(a)$ (4) (waiver of preferred standing provision), for reasons stated at notes $45-50$ supra and accompanying text.

Ship Mortgage Act $\S 922$ (d) (interport indorsement provision), for reasons stated in note 209 supra.

Ship Mortgage Act $\S 922$ (e) (mixed vessel-nonvessel security separate discharge provision), for reasons stated at notes 51-58 supra and accompanying text.

Ship Mortgage Act $\S 925(a)$, which provides for recording notice of an existing maritime lien. This section, not affecting lien status or rank, GrLmore \& Black 616, would be superfluous under the proposed system.

Ship Mortgage Act $\S 925$ (b) (certificate of mortgage discharge filed with Collector of Customs), which would be obsolete if the home port recordation system were abolished.

Ship Mortgage Act $\$ 926$ (b) (acknowledgment provision), for reasons stated in text at notes 210-11. supra.

Ship Mortgage Act $\$ 926$ (c) (refiling after change of home port), which would be obsolete if the home port recordation system were abolished.

Ship Mortgage Act $\S 927$ (Collector of Customs to keep records open for inspection and furnish certificates of recorded mortgages). The proposed federal bureau would 
A comprehensive statutory scheme must embrace some equipment generally or permanently located within one state. ${ }^{218}$ Since an inter-intra state use dichotomy would raise difficult problems of classification, all trucks should be made subject to the proposed statute. Moreover, the ease of converting an intrastate vehicle to interstate operation without the financer's consent would render any initial categorization commercially unreliable. The very equipment mobility which would accasion such problems suggests the constitutionality of the proposal. Similarly, inclusion of encumbrances on railroad fixed property should not raise constitutional doubts. Both intrastate trucks and railroad realty necessarily affect the flow of interstate commerce. ${ }^{219}$ Decisions upholding federal jurisdiction over intrastate air and ship security transactions would seem to allow such extended coverage. ${ }^{220}$ An additional constitutional base

allow free access to its records, note 215 supra, but should not issue such certificates to reduce possibility of governmental error, ibid.

Civil Aeronautics Act $\S 503$ (e) (acknowledgment provision), for reasons stated in text at notes $210-11$ supra.

The Interstate Commerce Act $\$ 20 \mathrm{c}$ also has an acknowledgment clause which should be eliminated. And Civil Aeronautics Act $\$ 503(\mathrm{~h})$, pertaining to the issuance and renewal of airworthiness certificates, is obviously unrelated to the proposed statute.

218. Equipment owned by the United States government, not within the scope of present recordation statutes, would also be excluded from the proposed act. The Ship Mortgage Act covers only vessels of the United States, by definition not governmentally owned. Rev. Stat. \$§ 4131-32 (1875), as amended, 46 U.S.C. $\$ \S 11,221$ (1952). Section 503 (a) (1) of the Civil Aeronautics Act is limited to privately owned (civil) aircraft as defined by 44 STAT. 573 (1926), as amended, 49 U.S.C. $\$ 179$ (e) (1952). Recording provisions of the Interstate Commerce Act do not involve the government since it neither owns nor operates railroads. Liens on equipment in the possession of dealers should also be excepted from the proposed statute. Dealer financing is usually effected through trust receipt transactions, Gilmore, Chattel Security: II, 57 Yale L.J. 761,765 (1948), which are adequately governed by the Uniform Trust Receipts Act, presently in force in thirtyone states, 9C UNIForm LAws ANN. 220 (1957). Moreover, the problem of regular interstate movement, with concomitant recordation difficulties, does not exist while inventory remains on a dealer's premises.

219. The commerce power, U.S. Const. art. 1, § 8, cl. 3, expanded by the Supreme Court to include many areas originally under state regulation, should suffice as a constitutional foundation. See United States v. South-Eastern Underwriters Ass'n, 322 U.S. 533 (1944) (insurance); United States v. Darby, 312 U.S. 100 (1941) (labor standards); Mulford v. Smith, 307 U.S. 38 (1939) (agriculture). See also Comment, $45 \mathrm{MrcH}$. L. REv. 1021 (1947). Directly in point are the doctrines of Wickard v. Filburn, 317 U.S. 111 (1942) (federal regulation of home-grown wheat for personal consumption sustained because of effect on interstate commerce), and The Daniel Ball, 77 U.S. (10 Wall.) 557 (1871.) (federal regulation of intrastate vessel upheld since goods carried part of the stream of commerce). See also Rosenhan v. United States, 131 F.2d 932, 935 (10th Cir. 1942), wherein the court stated: "It cannot be doubted that if the Federal Act is devoted to the promation of safety and efficiency in interstate commerce, whether it be the stagecoach, sailboat, steamship, railroad train, motor truck, or airplane, if the Act bears some reasonable and rational relationship to the subject over which it has assumed to act, the power is supreme and may not be denied, although it may include within its scope activities which are intrastate in character."

220. The constitutionality of the Ship Mortgage Act was upheld by the Supreme Court in Detroit Trust Co. v. The Thomas Barlum, 293 U.S. 21, 42-52 (1934). Section 503 of 
may be found in the federal bankruptcy power. ${ }^{221}$ Although historically limited to regulating insolvencies, the power over "the subject of bankruptcies" was intended to protect the national credit structure as well. ${ }^{222}$ Thus derived from

the Civil Aeronautics Act, not yet tested by the Supreme Court, was upheld in Blalock v. Brown, 78 Ga. App. 537, 51 S.E.2d 610 (1949) (leading case); In re Veterans' Air Express Co., 76 F. Supp. 684 (D.N.J. 1948). Contra, Aviation Credit Corp. v. Gardner, 174 Misc. 798, 22 N.Y.S.2d 37 (Sup. Ct. 1940), which declared in dictum that the act was unconstitutional if applied to planes engaged exclusively in intrastate commerce. Both the Blalock and Veterans' Air Express cases cite and reject this view. For discussion, see Mickelson, Aircraft Licn Law and Procedure, 44 ILL. B.J. 863, 864-67 (1.956). Moreover, broad congressional powers over the airways established by long standing legislation and a series of Supreme Court decisions presumes validation when a decisive test arises. 44 STAT. 572 (1926), as amended, 49 U.S.C. $\$ 176$ (a) (1952) ; Braniff Airways, Inc. v. State Bd. of Equalization and Assessment, 347 U.S. 590 (1954); Chicago \& Southern Air Lines, Inc. v. Waterman S.S. Corp., 333 U.S. 103 (1948) ; United States v. Causby, 328 U.S. 256 (1946). Counsel for institutional lenders universally accept the statute as valid. Adkins \& Billyou, Developments in Commercial Aircraft Equipment Financing, 13 Bus. Law. 199, 203 (1958).

While limited to equipment "used or intended for use in interstate commerce," the railroad rolling stock recordation act covers virtually every railroad car in the nation. For rolling stock belonging to the few intrastate rail carriers is constantly shifted to interstate trains and, consequently, falls within the statutory compass. See LockLIN, Econonrrcs of Transportation 609, 614-15 (3d ed. 1947); Adkins \& Billyou, Current Developments in Railroad Equipment Financing, 12 Bus. LAw. 207, 214 (1957). Were the proposed statute not so limited, its constitutionality would still seem assured. Cf. Seaboard Air Line R.R. v. Daniel, 333 U.S. 118 (1948) ; Houston, E. \& W. Tex. Ry. v. United States, 234 U.S. 342 (1914).

221. U.S. Const. art. I, \& 8, cl. 4.

222. 1 Collier, Bankruptcy $\llbracket 0.02$, at 5 (14th ed. 1956). See also ibid.: "Congress was to have an all-inclusive power through the bankruptcy grant to enact any legislation reasonably franted and related to the subject of bankruptcies, which in turn is indissolubly linked to commerce and credit." Cf. LoveLAND, BANKRUPTCY 20 (4th ed. 1912).

What little is known of the founding fathers' intentions supports this view. In the only recorded statement, James Madison observed: "The power of establishing uniform laws of bankruptcy, is so intimately connected with the regulation of commerce, and will prevent so many frauds where the parties or their property may lie, or be removed into different states, that the expediency of it seems not likely to be drawn into question." THE Federalist No. 42, at 336 (Hamilton ed. 1880) (Madison). See United States v. Pusey, 27 Fed. Cas. No. 16098, at 632 (C.C.E.D. Mich. 1872) ("The 'subject of bankruptcy' in a general sense, concerns the relation of debtor and creditor. ..."); In re Klein, 14 Fed. Cas. No. 7865, at 718 (C.C.D. Mo. 1843) ("[I]t [the bankruptcy power] extends to all cases where the law causes to be distributed the property of the debtor among his creditors; this is its least limit. Its greatest is a discharge of the debtor from his contracts. And all intermediate legislation, affecting substance and form, but tending to further the great end of the subject-distribution and discharge-are in the competency and discretion of congress"). See also In re Reiman, 20 Fed. Cas. 490, No. 11673 (S.D.N.Y. 1874) ; S. Doc. No. 65, 72d Cong., 1st Sess. 50 (1932). For a summary of the bankruptcy power's development during the nineteenth century, see Hanover Nat'l Bank v. Moyses, 186 U.S. 181. (1902).

Federal bankruptcy statutes have almost always been sustained. See WarREN, BankRUPTCY IN UNITED STATES HISTORY 9 (1935) (at publication date, only one bankruptcygrounded statute had been invalidated). However, the Municipal Debt Readjustment Act, 
either a bankruptcy or commerce foundation, federal power over ship, rail, air and truck carriers should be deemed as broad as the economic needs of these intrinsically interstate industries.

Act of May 24, 1934, c. 345, 48 StAr. 798, was avoided shortly thereafter in Ashton v. Cameron County Water Improvement Dist. No. One, 298 U.S. 513 (1936), over the strong dissent of four Justices. Writing for the minority, Mr. Justice Cardozo pointed out that the bankruptcy clause is a constantly expanding power; that every effort to widen it has met with bitter opposition, yet has eventually been approved. Id. at 536. The Cardozian philosophy prevailed. The Municipal Debt Readjustment Act was redrafted, re-enacted, 50 StAT. 653 (1937), as amended, 11 U.S.C. $\$ 401-04$ (1952), and upheld, United States v. Bekins, 304 U.S. 27 (1938).

See also remarks of Henry Clay, reprinted in WARREN, op. cit. supra at 159 , to the effect that the philosophy underlying the bankruptcy power is the nation's right fully to utilize its citizens' unimpaired facilities as producers and consumers. Clearly, this goal is not being attained for the trucking industry.

Apart from its effect on credit structures generally, secured commercial financing and lien recordation is directly linked to bankruptcy proceedings. See, e.g., Moore v. Bay, 284 U.S. 4 (1931) ; Constance v. Harvey, 215 F.2d 571 (2d Cir. 1954); In re Boston, 84 F. Supp. 594 (N.D. Tex. 1949).

Utilizing the bankruptcy power was suggested by one of the drafters of the Uniform Commercial Code in connection with possible federal adoption of that act. Braucher, Federal Enactment of the Uniform Commercial Code, 16 LAW \& Contesp. ProB. 100, 105 (1951). 